\title{
DO ROT
PHOTOSTAT
}

\section{CAUTHON}

This document coworn

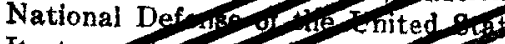

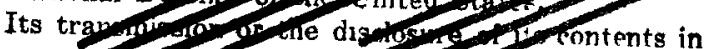
any minn an unauthororpen is prohbited and ma result in severe criminal peraltios uncer apphcable Federal Lav s

\section{RADIATION LABORATORY}




\section{DISCLAIMER}

This report was prepared as an account of work sponsored by an agency of the United States Government. Neither the United States Government nor any agency Thereof, nor any of their employees, makes any warranty, express or implied, or assumes any legal liability or responsibility for the accuracy, completeness, or usefulness of any information, apparatus, product, or process disclosed, or represents that its use would not infringe privately owned rights. Reference herein to any specific commercial product, process, or service by trade name, trademark, manufacturer, or otherwise does not necessarily constitute or imply its endorsement, recommendation, or favoring by the United States Government or any agency thereof. The views and opinions of authors expressed herein do not necessarily state or reflect those of the United States Government or any agency thereof. 


\section{DISCLAIMER}

Portions of this document may be illegible in electronic image products. Images are produced from the best available original document. 
UNIVERSITY OF CALIFORNIA

Radiation Laboratory

Cover Sheet

Do not remove
ICRL 764

INDEX NO.

This document contains $3 /$ pages

This is copy 73 of 96 series $A$

IsSuEd FECHNICAL INFORMATION DIVISION

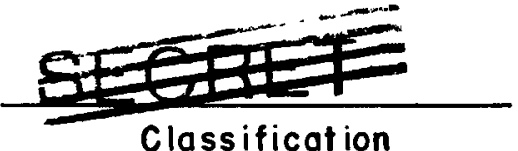

Classification

Each person who receives this document must sign the cover sheet in the space below

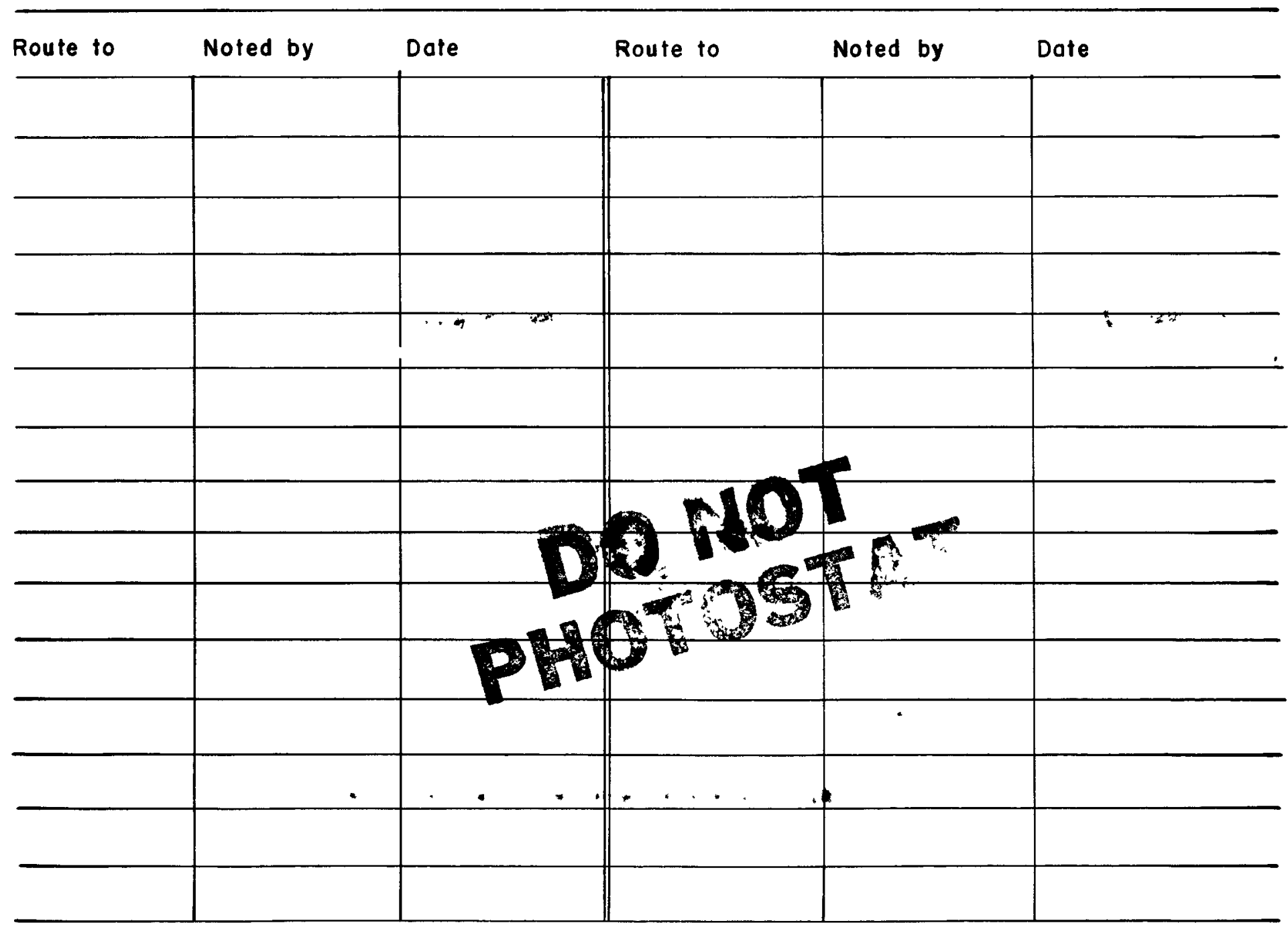



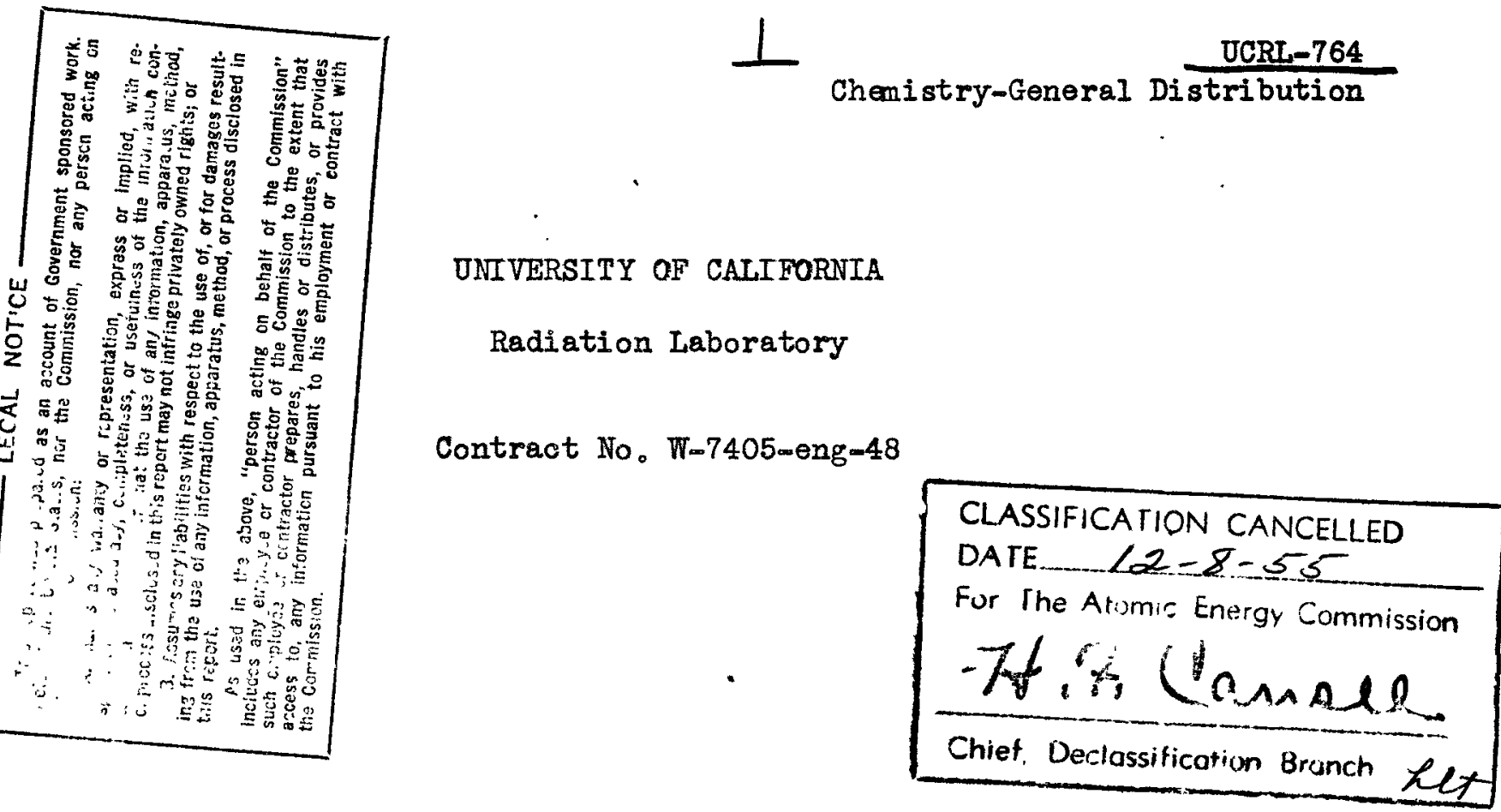

THE DISTRIBUTION OF TRACE URANIUN (VI) IN

NITRIC ACID--TTA--ORGANIC SOLVENT MIXTURES

D. L. Heìsig and H. W. Crandall

June 30,1950

Photostat Price $\$ \frac{4.80}{\square: 70:}$

Microfilm Price $\$: 2.70$.

Available from the

Office of Technical Services

Department of Commerce

Washington $25, \mathrm{D} . \mathrm{C}$.

Berkeley, California 


\author{
THE DISTRIBUTION OF TRACE URANIUM (VI) IN \\ NITRIC ACID--TTA--ORGANIC SOLVENT MIXTURES \\ D. L. Heisig and H. W. Crandall \\ Radiation Laboratory \\ University of California, Berkeley, California \\ June 30,1950 \\ INTRODUCTION
}

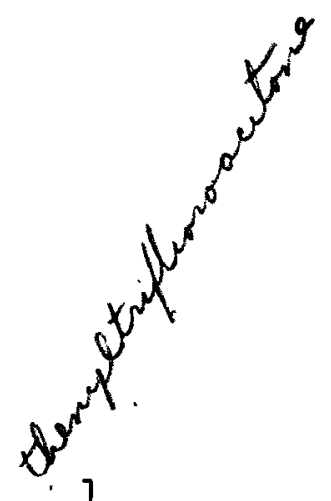

The distribution of uranium (VI) in benzene-water-perchloric acid-TTA mixtures has been studied by E. L. King ${ }^{2}$ and W. C. Orr. ${ }^{3}$ Orr reported the value of the equilibrium constant for the reaction

$$
2 \mathrm{HK}_{\text {benz. }}+\mathrm{UO}_{2}^{++} \text {aq. }=\mathrm{UO}_{2} \mathrm{~K}_{2_{\text {benz. }}}+2 \mathrm{H}^{+} \text {aq. }
$$

at $\mu=1.9$ of lithium perchlorate and perchloric acid as

$$
\mathrm{K}=\frac{\left(\mathrm{UO}_{2} \mathrm{~K}_{2}\right)\left(\mathrm{Y}_{\mathrm{UO}_{2} \mathrm{~K}_{2}}\right)}{\left(\mathrm{UO}_{2}{ }^{++}\right)} \frac{\left(\mathrm{H}^{+}\right)^{2}}{(\mathrm{HK})^{2}} \frac{1}{\gamma_{\mathrm{HK}^{2}}}=.0055
$$

Similar values are obtained from King's data. The distribution coefficients of trace uranium (VI) in the above system when TTA is $0.2 \mathrm{M}$ and nitric acid replaces perchloric acid have been measured by E. K. Hyde and J. Tolmach. 4

In this report the distribution coefficients of trace uranium (VI) in mixtures of dilute nitric acid and solutions of TTA in hexone, cyclohexanone, and pentaether are presented.

\title{
EXPERIMENTAL
}

In all the experiments $U^{233}$ was used, generally at about $5 \times 10^{-6}$ to $10^{-5} \mathrm{M}$. The experiments with hexone and many of those with cyclohexanone were run at room temperature on a $4 \mathrm{cc}$. scale in small flasks equipped with motor driven stirrers. In the pentaether experiments $2 \mathrm{cc}$. volumetric flasks were filled and placed on a revolving wheel in a $25^{\circ}$ thermostat. In all the experiments the volume ratio was one. 
Several experiments in hexone and cyclohexanone, using the motor driven stirrers, were followed as a function of time to determine the rate of equilibration. As one would expect from the fact that two to three hours are required for TTA initially in dry benzene to reach equilibrium between benzene and water, 5 the equilibration of uranium (VI), TTA, nitric acid, and hexone is slow, two to three hours, if the aqueous and organic phases are not equilibrated before the addition of the uranium (VI) (Table I). Equilibrium of the uranium (VI) in the preequilibrated phases was reached in less than fifteen minutes when a mechanical stirrer was used, although the rate varied with the speed of stirring. When samples were shaken on the revolving wheel, the phases were not equilibrated before the addition of uranium (VI). By making plates at the end of three and four hours it was shown that equilibrium had been reached by the end of three hours.

Plates were made from 50 to 100 人 portions of each phase and were counted with $\pm 1.5 \%$ accuracy.

Commercial grade hexone was used without any purification. Commercial cyclohexanone and pentaether were redistilled. The cyclohexanone used boiled at $153.1^{\circ} \mathrm{C}$. while the pentaether boiled at $190^{\circ} \mathrm{C}$ at $9 \mathrm{~mm}$. to $193^{\circ} \mathrm{C}$. at $11 \mathrm{~mm}$. The TTA was synthesized by M. W. Davis, Jr. and H. R. Lehman. The molarity of the solutions of TTA calculated from the weight of TTA used and from direct titration differed by less than $2 \%$.

\section{DISCUSSION}

When nitric acid, TTA, uranium (VI) and an organic solvent are mixed a number of reactions may take place.

In the aqueous phase:

(a) $\mathrm{UO}_{2}^{++}+\mathrm{NO}_{3}^{-}=\mathrm{UO}_{2} \mathrm{NO}_{3}^{+}$

(b) $\mathrm{UO}_{2}^{++}+2 \mathrm{NO}_{3}^{-}=\mathrm{UO}_{2}\left(\mathrm{NO}_{3}\right)_{2}$

(c) $\mathrm{UO}_{2}^{++}+\mathrm{HK}_{\mathrm{aq}}=\mathrm{UO}_{2} \mathrm{~K}^{+}+\mathrm{H}^{+}$ 
(d) $\mathrm{UO}_{2}^{++}+2 \mathrm{HK}_{\mathrm{aq} \cdot}=\mathrm{UO}_{2} \mathrm{~K}_{2}+2 \mathrm{H}^{+}$

In the two phase system:

(1) $\mathrm{UO}_{2}^{++}+2 \mathrm{NO}_{3}-\stackrel{\mathrm{K}_{1}}{=} \mathrm{UO}_{2}\left(\mathrm{NO}_{3}\right)_{2}$ org.

(2) $\mathrm{UO}_{2}^{++}+\mathrm{NO}_{3}^{-}+\mathrm{HK}_{\text {org. }} \stackrel{\mathrm{K}_{2}}{=} \mathrm{UO}_{2} \mathrm{NO}_{3} \mathrm{~K}_{\text {org. }}+\mathrm{H}^{+}$

(3) $\mathrm{UO}_{2}^{++}+2 \mathrm{HK}$ org. $\stackrel{\mathrm{K}_{3}}{=} \mathrm{UO}_{2} \mathrm{~K}_{2}+2 \mathrm{H}^{+}$

(4) $\mathrm{H}^{+}+\mathrm{NO}_{3}-\stackrel{\mathrm{K}_{4}}{=} \mathrm{HNO}_{3}$ org.

E. I. King's data ${ }^{2}$ and those of W. C. Orr ${ }^{3}$ with perchloric acid--TTA--benzene mixtures indicate that little complexing of uranyl ion with TTA occurs in the aqueous phase, Reactions (c) and (d), when the hydrogen ion and TTA concentrations in the aqueous phase are in the range of those used in the experiments in this report. King found that a plot of $\log \mathrm{E}^{\prime}=\log \frac{(\mathrm{U} \text { org. })^{\gamma_{U O_{2}} \mathrm{~K}_{2}}}{(\mathrm{U} \text { aq.) }}$ vs. $\log (\operatorname{TTA})\left(\boldsymbol{Y}_{\mathrm{TMA}}\right)$ at constant acid gave a straight line with a positive slope of two which is the theoretical slope for Reaction (3) involving the uncomplexed urangl ion. Orr estimated that the value of the equilibrium constant for Reaction (c) is about 0.15 . With this value the fraction of $\mathrm{UO}_{2}^{++}$complexed as $\mathrm{UO}_{2} \mathrm{~K}^{+}$in the aqueous phase was calculated and found to be less than one percent under the most favorable complexing conditions used, e.g., Experiment C29 with $0.0745 \underline{M}$ nitric acid and $0.001 \mathrm{M}$ TTA in the aqueous phase. The concentration of the TTA in the water phase was calculated from the distribution coefficient of TTA in a mixture of pentaether and $0.15 \mathrm{TM}$ nitric acid, which was found to be approximately 300 by $\mathrm{H}$. W. Crandall and D. L. Heisig. From these considerations it was concluded that Reactions (c) and (d) are of little importance in this system.

At $8.0 \mathrm{M}$ total salt concentration the constants for Reactions (a) and (b) have been calculated from distribition measurements between benzene and an aqueous 
phase and reported as ${ }^{7}$

$$
\begin{aligned}
& \mathrm{K}_{\mathrm{a}}=\frac{\left(\mathrm{UO}_{2} \mathrm{NO}_{3}{ }^{+}\right)}{\left(\mathrm{UO}_{2}{ }^{++}\right)\left(\mathrm{NO}_{3}{ }^{-}\right)}=.116 \text { and } \\
& \mathrm{K}_{\mathrm{b}}=\frac{\mathrm{UO}_{2}\left(\mathrm{NO}_{3}\right)_{2}}{\left(\mathrm{UO}_{2}^{++}\right)\left(\mathrm{NO}_{3}^{-}\right)^{2}}=.031
\end{aligned}
$$

More recently R. H. Betts and Rita K. Michels ${ }^{8}$ have determined the value of $K_{a}$ from absorption data. Their value is 0.21 at $\mu=5.4$, and these authors state that the presence of a second complex is doubtful at this salt concentration.

All of the uranium in the aqueous phase can be represented by the equation

(5) $\mathrm{U}_{\mathrm{aq} .}=\left(\mathrm{UO}_{2}^{++}\right)+\left(\mathrm{UO}_{2} \mathrm{NO}_{3}^{+}\right)+\left(\mathrm{UO}_{2}\left(\mathrm{NO}_{3}\right)_{2}\right)=\left(\mathrm{UO}_{2}^{++}\right)\left[1+\mathrm{K}_{\mathrm{a}}\left(\mathrm{NO}_{3}{ }^{-}\right)+\mathrm{K}_{\mathrm{b}}\left(\mathrm{NO}_{3}{ }^{-}\right)^{2}\right]$ where activity effects are neglected. This equation shows that constants or distribution coefficients calculated on the basis that $\mathrm{U}_{\mathrm{aq}}=\left(\mathrm{UO}_{2}{ }^{++}\right)$will be in error from 1 to $2 \%$ at $0.1 \mathrm{M}\left(\mathrm{NO}_{3}{ }^{-}\right)$to 15 to $20 \%$ at $\mathrm{IM}\left(\mathrm{NO}_{3}{ }^{-}\right)$depending on which constants are used. For a given nitrate ion concentration the fraction of uranyl ion complexed is constant, and in this report corrections for obtaining the fraction of $\mathrm{UO}_{2}^{++}$uncomplexed by nitrate ion are not used. Nitrate complexing will account for part of the variation of the constants $K_{1}, K_{2}$, and $K_{3}$ with nitric acid concentrations.

Corresponding to Equations (1), (2), (3), and (4) are the following extraction coefficients and equilibrium constants where subscript, designates the concentration in moles per liter in the organic phase.

$$
\begin{aligned}
& \text { (6) } \mathrm{K}_{1}=\frac{\left(\mathrm{UO}_{2}\left(\mathrm{NO}_{3}\right)_{2}\right)_{0}}{\left(\mathrm{UO}_{2}^{++}\right)\left(\mathrm{NO}_{3}^{-}\right)^{2}}=\mathrm{K}_{1} \circ \frac{\mathrm{YUO}_{2}^{++} \mathrm{Y}^{2} \mathrm{NO}_{3}-}{\gamma_{\mathrm{UO}_{2}}\left(\mathrm{NO}_{3}\right)_{2}}=\frac{\mathrm{E}_{1}}{\left(\mathrm{NO}_{3}^{-}\right)^{2}} \\
& \text { (7) } \mathrm{K}_{2}=\frac{\left(\mathrm{UO}_{2} \mathrm{NO}_{3} \mathrm{~K}\right)_{0}\left(\mathrm{H}^{+}\right)}{\left(\mathrm{UO}_{2}^{++}\right)\left(\mathrm{NO}_{3}^{-}\right)(\mathrm{HK})_{0}}=\mathrm{K}_{2}^{\circ} \frac{\gamma_{\mathrm{UO}_{2}}^{++} \mathrm{Y}_{\mathrm{NO}_{3}}-\gamma_{\mathrm{HK}}}{\gamma_{\mathrm{UO}_{2} \mathrm{NO}_{3} \mathrm{~K} \gamma_{\mathrm{H}}}}
\end{aligned}
$$




$$
\begin{aligned}
& \text { (8) } \mathrm{K}_{3}=\frac{\left(\mathrm{UO}_{2} \mathrm{~K}_{2}\right)_{0}\left(\mathrm{H}^{+}\right)^{2}}{\left(\mathrm{UO}_{2}^{++}\right)(\mathrm{HK})_{0}^{2}}=\mathrm{K}_{3}^{\circ} \frac{\mathrm{YUO}_{2}{ }^{++} \gamma^{2} \mathrm{HK}}{\gamma_{\mathrm{UO}_{2} \mathrm{~K}_{2} \gamma^{2} \mathrm{H}^{+}}} \\
& \text {(9) } \mathrm{K}_{4}=\frac{\left(\mathrm{HNO}_{3}\right)_{\mathrm{O}}}{\left(\mathrm{H}^{+}\right)\left(\mathrm{NO}_{3}^{-}\right)}=\frac{\mathrm{E}_{\mathrm{HNO}_{3}}}{\left(\mathrm{NO}_{3}^{-}\right)} \\
& \text {(10) } \mathrm{E}_{\mathrm{M}}=\frac{\mathrm{c} / \mathrm{m} / 100 \lambda \text { in org. phase }}{\mathrm{c} / \mathrm{m} / 100 \lambda \text { in aq. phase }}
\end{aligned}
$$

In general

$$
\text { (II) } E_{M}=\frac{\left(\mathrm{UO}_{2} \mathrm{~K}_{2}\right)_{0}+\left(\mathrm{UO}_{2} \mathrm{KNO}_{3}\right)_{0}+\left(\mathrm{UO}_{2}\left(\mathrm{NO}_{3}\right)_{2}\right)_{0}}{\left(\mathrm{UO}_{2}^{++}\right)}=\frac{\left(\mathrm{UO}_{2} \mathrm{~K}_{2}\right)_{0}+\left(\mathrm{UO}_{2} \mathrm{KNO}_{3}\right)_{0}}{\left(\mathrm{UO}_{2}^{++}\right)}+\mathrm{E}_{1}
$$

Combination of Equations (11), ( 7$)$, and (8) gives

or (13) $\mathrm{E}_{\mathrm{M}^{-}} \mathrm{E}_{1}=\frac{(\mathrm{HK})_{0}^{2}}{\left(\mathrm{H}^{+}\right)^{2}} \mathrm{~K}_{3}+\frac{(\mathrm{HK})_{\mathrm{O}}\left(\mathrm{NO}_{3}^{-}\right)}{\left(\mathrm{H}^{+}\right)} \mathrm{K}_{2}$

$$
\text { (12) } \mathrm{E}_{\mathrm{M}}=\frac{(\mathrm{HK})_{0}^{2}}{\left(\mathrm{H}^{+}\right)^{2}} \frac{\gamma_{\mathrm{HK}}^{2}}{\gamma_{\mathrm{UO}_{2} \mathrm{~K}_{2}}} \frac{{\mathrm{YUO}_{2}}^{++}}{\gamma_{\mathrm{H}^{+2}}} \mathrm{~K}_{3}{ }^{0}+\frac{(\mathrm{HK})_{\mathrm{O}}\left(\mathrm{NO}_{3}{ }^{-}\right)}{\left(\mathrm{H}^{+}\right)} \frac{\gamma_{\mathrm{UO}_{2}}^{++} \gamma_{\mathrm{HK}} \gamma_{\mathrm{NO}_{3}}^{-}}{\gamma_{\mathrm{H}^{+}}{ }^{+} \mathrm{YUO}_{2} \mathrm{NO}_{3} \mathrm{~K}} \mathrm{~K}_{2}^{0}+\mathrm{E}_{1}
$$

The nitric acid distribution, Reaction (4), between water and the organic liquid was determined by titration or had been determined previously. ${ }^{9,10}$ These values together with the distribution coefficients, $E_{1}$, of uranyl nitrate between dilute nitric acid and each of the organic solvents in the absence of TTA are recorded in Columns 8 and 9 of Table II. Volume changes were known in the pentaether system only and in this system no corrections were necessary except at nitric acid concentrations greater than one molar. Since both the nitric acid and uranium (VI) distribution coefficients were determined by analyzing equal volumes of the organic and aqueous phases only the TTA concentration had to be corrected for the volume changes. If sodium nitrate was used in the experiment, $E_{1}$, differed from the value obtained at the same equilibrium nitrate concentration in the aqueous phase with nitric acid alone. This was especially noticeable at high ionic strengths and is probably due to activity effects and to differences in the 
UCRL-764

Page 8

concentration of the nitric acid in the organic phase. In hexone, $\mathrm{E}_{1}$ was neglected since it is small compared to the corresponding $\mathrm{E}_{\mathrm{M}^{\circ}}$

That both Reactions (2) and (3) contribute to the distribution coefficient of uranium (VI) in these solvents can be seen from the data for both pentaether and for cyclohexanone. (Tables III to VII, and Figures 1 to 7.) In Figures 1, 2, 3, 4, and 6 the experimental data are represented by points while the lines drawn are theoretical curves calculated from the constants described in a later section of this report. At high TTA concentrations and low nitric acid concentrations the first term in the right hand side of Equation (13) should be la rge compared to the second, providing $K_{2}$ and $K_{3}$ are of comparable magnitude. Under these conditions and at constant nitrate and hydrogen ion concentrations, neglecting activity effects, Equation (13) becomes

(14) $\log \left(E_{M}-E_{1}\right)=2 \log H K+$ Constant.

The experimental points along $C$ arves $A$ and $B$, Figures 1 and 2 , taken from data in Tables III and V satisfy the above condition; of low nitrate and high TTA, and lie on curves whose slope is plus two. Only a approximation is expected as activity coefficients are omitted.

Similarly, at high nitric acid concertration and low TTA concentration the second term in Equation (13) predominates and at constant hydrogen and nitrate ion concentration, neglecting activity effects, Equation (13) becomes

(15) $\log \left(E_{M}-E_{l}\right)=\log H K+$ Constant.

The experimental points along Curve D, Figure 2, and Curve E, Figure 1, satisfy the above conditions, and the slopes of the curves drawn through the experimental points approach plus one. Figures 1 and 2 show that as the nitric acid concentration is increased the TTA dependence on $\left(E_{M}-E_{1}\right)$ at constant ionic strength decreases from two to one in agreement with Equation (13). 
Figures 3 and 4 are plots of $\log \left(H^{+}\right)$vs. $\log \left(E_{M}-E_{1}\right)$ at constant TTA concentration using the data in Tables III and V. From Equation (13) two extremes are predictable for the hydrogen ion dependence on $\left(E_{M}-E_{1}\right)$ where the TTA concentration is constant and activity effects are neglected. At low hydrogen ion concentration and high TTA concentration the first term on the right hand side of Equation (13) predominates and

(16) $\log \left(E_{M}-E_{1}\right)=-2 \log \left(H^{+}\right)+$Constant. The slopes of curves connecting the experimental points at low nitric acid concentration in Figures 3 and 4 approach a limit of minus two. At high nitric acid concentration and IOW TTA concentration Equation (13) reduces to

(17) $\log \left(E_{M}-E_{I}\right)=0 \log \left(H^{+}\right)+$Constant provided that nitric acid is the only source of nitrate and hydrogen ions. The slopes of the curves connecting the experimental points at high nitric acid concentration in Figures 3 and 4 approaches zero.

The dependence of $\left(E_{M}-E_{1}\right)$ on the hydrogen ion concentration when the ionic strength and the nitrate ion concentration are maintained constant is shown in Figure 6 from the data in Tables IV and VI.

Slopes of -1.1 in cyclohexanone and -2.0 in pentaether are obtained in regions where the slopes predicted from Equation (13) using the constants obtained at the same ionic strength but at constant nitric acid concentration are -1.0 and -2.0 , respectively. Figures 3,4 , and 6 show that as the nitric acid concentration is increased, the hydrogen ion dependence on $\left(E_{M}-E_{l}\right)$ at a given TTA concentration increases from minus two to zero if nitric acid is the only source of nitrate and hydrogen ions and to minus one if sodium nitrate is present. Thus, they support the mechanism summarized by Equation (13).

The nitrate dependence at high nitrate ion concentration and low TTA concentration is shown by Figure 7 from the data in Tables IV and VI. In Figure 7 the 
lines shown connect the experimental points and are not calculated. The data used in Tables IV and VI are less accurate than most of the other data. In the case of the experiments in pentaether $\left(E_{M}-E_{1}\right)$ represents the difference between two distribution coefficients of comparable size, e.g., $E_{I}=0.485$ and $E_{M}=0.730$. Furthermore, $E_{1}$ and $E_{M}$ are calculated from counting plates which contain sodium nitrate in varying amounts. The values of $E_{1}$ in cyclohexanone which are recorded in Table VI are extrapolated from a graph of $E_{1}$ measured when nitric acid was the only nitrate source against the concentration of nitric acid in the aqueous phase after equilibrium had been reached. It was assumed that $E_{1}$ for a given nitrate concentration was independent of the cation. This is not exactly true, but gives an indication of $\left(E_{M}-E_{1}\right)$ for the experiments in Table VI. The counting for these experiments was also done in the presence of sodium nitrate which reduces the counting accuracy. The ionic strength varied from 0.6 to 0.9 in the nitrate dependence experiments in pentaether, and from 0.4 to 0.6 and 0.6 to 0.9 in cyclohexanone. With this change in ionic strength the activity coefficients of nitric acid $d^{11}$ as well as those of uranyl nitrate ${ }^{12}$ vary less than ten percent, but it is not known how the activities of the uranium complexes in the organic phases vary. However, since the over-all change in the ionic strength is rather small for each series, and since the nitrate dependence is observed in regions in which it was independently predicted from the variation of $\left(E_{M}-E_{I}\right)$ with TTA and hydrogen ion concentrations, it is believed that the nitrate dependence curves are real.

The maximum experimental error in these determinations is probably not more than $20 \%$ and reproducibility seems to be nearer $10 \%$. If the two extreme points in Curve $C$, Figure 7 are taken and if it is assumed that the upper point is actually $20 \%$ less and the lower curve is $20 \%$ greater than that recorded a line of slope 0.3 is obtained, an indication that the inaccuracies of the measurements cannot account for the nitrate dependence curves. 
The hexone data in Table VIII are insufficient to demonstrate that both Equations (2) and (3) apply to the hexone system. However, in Figure 5 a plot of $\log E_{M}$ vs. $\log$ TTA at two hydrogen ion concentrations shows a decrease of slope from 1.8 to 1.6 as the equilibrium nitric acid concentration increases from 0.23 to 0.43 paralleling the trend in Figures $I$ and 2 for pentaether and cyclohexanone. This supports the supposition that the extraction mechanism of uranium (VI) by TTA is the same in hexone as it is in pentaether and cyclohexanone and can be represented by Equations (1), (2), and (3).

\section{ACTIVITY EFFECTS}

Insertion of activity coefficients in any of the equations mentioned will not alter the qualitative picture just presented of the mechanism of extraction of uranium (VI) into cyclohexanone, hexone, and pentaether. When the ionic strength and the nitric acid concentration are constant, Figures 1 and 2 , the only activities changing are those of $\mathrm{TTA}, \mathrm{UO}_{2} \mathrm{~K}_{2}, \mathrm{UO}_{2} \mathrm{KNO}_{3}$, and $\mathrm{UO}_{2}\left(\mathrm{NO}_{3}\right)_{2}$ in the organic phase. The activity coefficients of TTA in pentaether which has been equilibrated with $0.5 \mathrm{M}$ nitric acid have been measured. ${ }^{6}$ In going from $0.045 \mathrm{M}$ TTA to $0.378 \mathrm{M}$ TTA the activity coefficient of TTA increases from 1.01 to 1.19 . If $\log \left(E_{M}-E_{1}\right)$ is plotted against $\log$ (TTA) $\Upsilon_{\text {TTA }}$ using the data in Curves A and B, Figure 1, a slope of 1.9 as compared to 2.0 without the activity coefficients is obtained.

It is not known whether the activity coefficient of the uranium complexes in the organic phase increases or decreases with TTA. In benzene the form is $\mathrm{UO}_{2} \mathrm{~K}_{2}$ and its activity coefficient is known to decrease with TTA presumably due to the formation of $\mathrm{UO}_{2} \mathrm{~K}_{2} \cdot \mathrm{HK}^{2,3}$ However, TTA is known to interact strongly with pentaether $\left(\frac{\text { TTA }_{\text {org }}}{\text { TTA }_{\text {aq. }} \text {. }}=300\right.$ in pentaether as compared to 40 in benzene), 6 and $\mathrm{UO}_{2} \mathrm{~K}_{2}$ as evidenced from its one hundred fold increase in extractability in pentaether as compared to benzene, also appears to interact strongly with 
UCRL-764

Page 12

pentaether. 'Hence, it is probable that the activity coefficient of $\mathrm{UO}_{2} \mathrm{~K}_{2}$ will decrease much less rapidly with the TTA concentration in pentaether than in benzene since the complex $\mathrm{UO}_{2} \mathrm{~K}_{2}{ }^{\circ} \mathrm{HK}$ is less likely to form. In fact, like the activity coefficient of TTA in pentaether, that of $\mathrm{UO}_{2} \mathrm{~K}_{2}$ may increase with increasing TTA concentrations, and it seems reasonable to assume that the behavior of $\mathrm{UO}_{2} \mathrm{KNO}_{3}$ is similar to that of $\mathrm{UO}_{2} \mathrm{~K}_{2}$ under these conditions. In this event the changes in the activity coefficients of $\mathrm{UO}_{2} \mathrm{~K}_{2}$ and $\mathrm{UO}_{2} \mathrm{KNO}_{3}$ tend to cancel the increase of $\gamma_{\text {TTA }}$ and the activity effects at constant aqueous phase composition would be small. Further discussion of the interaction of TTA and pentaether will be found in another report from this laboratory. 6

On the other hand when the TTA concentration is held constant and the nitric acid concentration is varied, the activities of the $\mathrm{TTA} \mathrm{UO}_{2} \mathrm{~K}_{2}$, and $\mathrm{UO}_{2} \mathrm{KNO}_{3}$ in the organic phase are not constant since it is known that the composition of the organic phase as well as the activity of TTA in pentaether changes with the concentration of nitric acid in the aqueous phase. Large variations of the constants $K_{2}$ and $K_{3}$ are observed as the ionic strength increases from 0.1 to 1.0 .

However, the experiments in Figure 6 from the data in Tables IV and VI were carried out at constant ionic strength as well as constant TTA concentration. Under these conditions the activity coefficients in both phases should be fairly constant, especially since the total nitrate ion concentration is constant and the hydrogen ion concentration is varied over a limited range only. Since the activity effects at constant ionic strength are small, any changes in the piot of $\log \left(E_{M}-E_{1}\right)$ vs. $\log \left(\mathrm{H}^{+}\right)$in Figure 6 that would result from the use of activity corrections must also be small, and so could not alter the qualitative agreement already noted between the data in Figure 6 and the extraction mechanism for uranium (VI) summarized by Equation (13)。Furthermore, since the experiments in Figures 3 and 4 where the ionic strength is varied agree qualitatively with the results obtained at 
constant ionic strength, it is believed that the use of activity coefficients where the ionic strength is varied will not invalidate the trends previously observed in Figures 3 and 4.

\section{CALCULATION OF CONSTANTS}

Although the data presented here indicate that the distribution of uranium (VI) between dilute nitric acid and cyclohexanone, hexone, or pentaether is represented by Equations (1), (2), and (3), the absolute values of the constants $\mathrm{K}_{1}{ }^{0}, \mathrm{~K}_{2}{ }^{0}$, and $\mathrm{K}_{3}{ }^{0}$ cannot be determined since the only activity coefficients known in these systems are those of TTA in pentaether. For pentaether and cyclohexanone, values for $\mathrm{K}_{2}$ at high nitrate and low TTA concentrations and for $\mathrm{K}_{3}$ at high TTA and low nitric acid concentrations can be calculated directly from the data, and these constants are given in Columns 7 and 8 of Tables III and V, and Column 11 of Tables IV and VI. It was found in all cases where data were available that at a given ionic strength the same value of a given constant was obtained when nitric acid was present alone in the aqueous phase as when nitric acid and sodium nitrate were both present.

Furthermore, it can be shown from Equation (13) that under the conditions where each of these constants is calculated the term in Equation (13) involving the other constant at its maximum value contributes less than 10 percent of the measured value of $\left(E_{M}-E_{1}\right)$ and can justifiably be neglected in the calculation. The starred values of $\mathrm{K}_{2}$ and $\mathrm{K}_{3}$ are calculated under conditions where the term in Equation (13) involving the other constant at the value recorded in Column 6 of Tables III and V, and Column 10 of Tables IV and VI contributes less than 10 percent of the measured value of $\left(E_{M}-E_{l}\right)$. Examples of these calculations are shown in Table VIII.

The constant values of $K_{3}$ at $\mu=0.0745$ in pentaether and those of $K_{2}$ at $u=0.385$ in cyclohexanone indicate that for TTA concentrations from 0.04 to $0.4 \underline{M}$ 
$\frac{\gamma_{\mathrm{OO}_{2} \mathrm{~K}_{2}}}{\gamma_{\mathrm{HK}}{ }^{2}}$ and $\frac{\gamma_{\mathrm{UO}_{2} \mathrm{KNO}_{3}}}{\gamma_{\mathrm{HK}}}$ are constant within the experimental error if the ionic strength is constant. By assuming as a first approximation that $K_{2}$ and $K_{3}$ were Independent of the TTA concentration rough values of $\mathrm{K}_{2}$ and $\mathrm{K}_{3}$ were assigned at various nitric acid concentrations where they could not be calculated directly from the data. These constants, which are recorded in Column 6 of Tables III and V, and Column 10 of Tables IV and VI are of the proper order of magnitude only and in some cases can be varied up to $20 \%$ and fit the data as well.

Figure 8 is a plot of $K_{2}$ and $K_{3}$ as well as the measured values of $E_{1}$ vs. the nitric acid concentration in the aqueous phase at equilibrium from the data in Columns 3 and 6 of Tables III and V and Columns 3 and 10 of Table VI. From these constants values of $\mathrm{E}_{\mathrm{M}}$ can be calculated with an accuracy of $15 \%$ when the nitric acid and TTA concentrations are 0 to $0.9 \mathrm{M}$ and 0 to $0.6 \mathrm{M}$, respectively, in pentaether and 0 to $0.8 \mathrm{M}$ and 0 to $0.5 \mathrm{M}$ in cyclohexanone. The calculated values of $\left(E_{M}-E_{1}\right)$ are shown in Column 6 of Tables III and $V$ and in Column 10 of Tables IV and VI and are represented by the curves drawn in Figures 1, 2, 3, 4, and 6. SUMMARY thenyltrifluaroacetone, $1:$ 1. The distribution of uranium (VI) in systems of nitric acid,)(TTA) and a if ic hexone, cyclohexanone, or pentaether has been shown to depend upon three, reactiong )

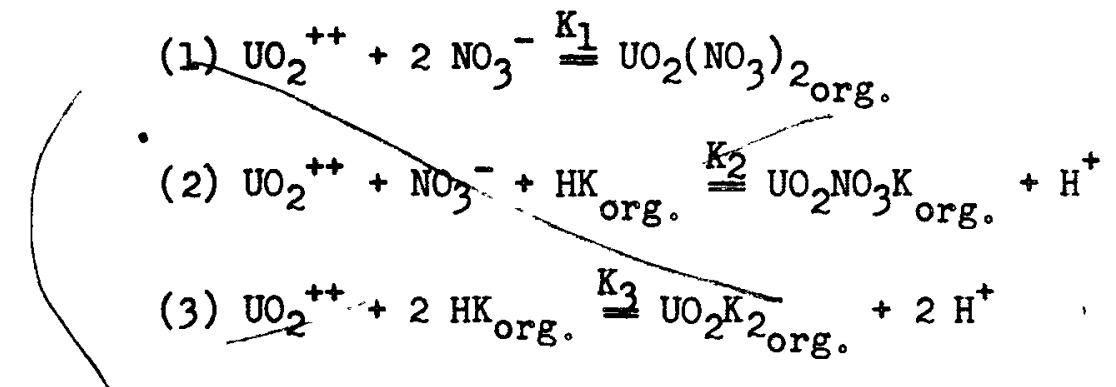

Q. The values of the equilibrium constants in pentaether and cyclohexanone when activity effects are neglected have been estimated at various nitric acid concentrations. 
UCRL-764

Page 15

\begin{abstract}
6. These constants can be used to calculate the distribution coefficient of uranium (VI) with an accuracy of 15 percent in pentaether-nitric acid mixtures containing up to $1.42 \mathrm{M}$ total nitric acid and $0.6 \mathrm{M} \mathrm{TTA}$ and in cyclohexanone-nitric acid mixtures containing up to $1.0 \mathrm{M}$ total nitric acid and 0.5M TTA. (auth)
\end{abstract}




\section{Table I}

Equilibration of Uranium (VI) in

Hexo ne-TTA-Nitric Acid Systems

Experiment No. A5

Conditions: $0.444 \mathrm{M} \mathrm{HNO}_{3}, 0.375 \mathrm{M}$ TTA in hexone. No equilibration of phases, prior to the addition of $\mathrm{U}^{233}$.

\begin{tabular}{llcc}
\hline $\begin{array}{l}\text { Time } \\
\text { Min. }\end{array}$ & $\begin{array}{l}\text { Counts/Min。 } \\
\text { Per 100K } \\
\mathrm{Aq} \text {. Phase }\end{array}$ & $\begin{array}{l}\text { Time } \\
\text { Min. }\end{array}$ & $\begin{array}{l}\text { Counts/Min. } \\
\text { Per 100K } \\
\text { Aq. Phase }\end{array}$ \\
\hline 0 & 1300 & 15 & 540 \\
.5 & 469 & 60 & 729 \\
1.0 & 328 & 126 & 834 \\
2.0 & 354 & 210 & 850 \\
\hline
\end{tabular}

Experiment No. AlO

Conditions: $0.444 \mathrm{M} \mathrm{HNO}_{3}, 0.375 \mathrm{M}$ TTA in hexone. Phases equilibrated several hours before addition of $\mathrm{U}^{233}$.

\begin{tabular}{cc}
\hline $\begin{array}{c}\text { Time } \\
\text { Min. }\end{array}$ & $\begin{array}{l}\text { Counts/Min. } \\
\text { Per 100K } \\
\text { Aq. Phase }\end{array}$ \\
\hline 0 & 1280 \\
.5 & 868 \\
1.5 & 819 \\
3.0 & 790 \\
20.0 & 797
\end{tabular}

* The rise in the $U^{233}$ concentration in the aqueous phase following its first dip occurs as TTA diffuses into the aqueous phase. 5 
UCRL-764

Page 17

Table II

Distribution of Uranium Nitrate and Nitric Acid Between Equal Volumes of Water and Various Organic Solvents in the Absence of TTA

\begin{tabular}{|c|c|c|c|c|c|c|c|c|}
\hline \multirow{3}{*}{$\begin{array}{l}\text { Solvent } \\
\text { Hexone } \\
\text { (A) }\end{array}$} & \multirow{3}{*}{$\begin{array}{l}\text { Ex. No. } \\
\text { B48 }\end{array}$} & \multirow{2}{*}{$\frac{\text { Initial }}{\mathrm{UO}_{2}\left(\mathrm{NO}_{3}\right)_{2}}$} & \multirow{2}{*}{$\frac{\text { Aqueous }}{\mathrm{HNO}_{3} \mathrm{M}}$} & \multirow{2}{*}{$\frac{\text { hase }}{\mathrm{NaNO}_{3} \mathrm{M}}$} & \multirow{2}{*}{\multicolumn{2}{|c|}{$\frac{\text { Equilibrium }}{\mathrm{HNO}_{3} \mathrm{M}(\overline{\mathrm{B}})}$}} & \multicolumn{2}{|c|}{ Earg. } \\
\hline & & & & & & & $\mathrm{UO}_{2}^{\mathrm{E}_{1}}\left(\mathrm{NO}_{3}\right)$ & $\begin{array}{c}\mathrm{E} \\
\mathrm{HNO}_{3}\end{array}$ \\
\hline & & $4 \times 10^{-6}$ & $\begin{array}{l}.252 \\
.504 \\
.350\end{array}$ & & $\begin{array}{l}.008 \\
.029 \\
.011\end{array}$ & $\begin{array}{l}.244 \\
.475 \\
.339\end{array}$ & .0055 & $\begin{array}{l}.033 \\
.061 \\
.032\end{array}$ \\
\hline $\begin{array}{l}\text { Cyclo- } \\
\text { hexanone }\end{array}$ & $\begin{array}{l}\text { B47 } \\
\text { B17 } \\
\text { B16 } \\
\text { B46 } \\
\text { B27 } \\
\text { B39 } \\
\text { B29 }\end{array}$ & $\begin{array}{l}4 \times 10^{-6} \\
4 \times 10^{-6} \\
4 \times 10^{-6} \\
4 \times 10^{-6} \\
4 \times 10^{-6} \\
4 \times 10^{-6} \\
4 \times 10^{-6}\end{array}$ & $\begin{array}{r}.157 \\
.157 \\
.467 \\
.467 \\
.467 \\
1.269 \\
.101 \\
.234 \\
.479 \\
.985 \\
.985 \\
0 \\
0\end{array}$ & $\begin{array}{l}.948 \\
.948\end{array}$ & $\begin{array}{l}.013 \\
.012 \\
.087 \\
.088 \\
.093 \\
.422 \\
.007 \\
.031 \\
.094 \\
.246 \\
.246\end{array}$ & $\begin{array}{l}.144 \\
.145 \\
.380 \\
.379 \\
.374 \\
.847 \\
.094 \\
.203 \\
.385 \\
.739 \\
.739\end{array}$ & $\begin{array}{l}\text { 1) } \\
.017 \\
.058 \\
.182 \\
.549 \\
.522 \\
.73 \\
.68\end{array}$ & $\begin{array}{l}.090 \\
.083 \\
.229 \\
.232 \\
.249 \\
.498 \\
.074 \\
.152 \\
.244 \\
.333 \\
.333\end{array}$ \\
\hline $\begin{array}{l}\text { Penta- } \\
\text { ether }\end{array}$ & $\begin{array}{l}C 30 \\
C 12 \\
C 2 \\
C 4 \\
C 3 \\
C 1 \\
C 41 \\
C 55 \\
C 56 \\
C 57 \\
C 67 \\
C 58 \\
C 68 \\
C 59 \\
C 63 \\
C 65 \\
C 69\end{array}$ & $\begin{array}{l}10^{-5} \\
10^{-5} \\
4 \times 10^{-6} \\
4 \times 10^{-6} \\
4 \times 10^{-6} \\
4 \times 10^{-6} \\
10^{-5} \\
10^{-5} \\
10^{-5} \\
10^{-5} \\
10^{-5} \\
10^{-5} \\
10^{-5} \\
10^{-5} \\
10^{-5} \\
10^{-5} \\
10^{-5}\end{array}$ & $\begin{array}{l}.0788 \\
.158 \\
.473 \\
.473 \\
.788 \\
.788 \\
1.42 \\
.0315 \\
.788 \\
.788 \\
.788 \\
.788 \\
.788 \\
.788 \\
.788 \\
.788 \\
.788\end{array}$ & $\begin{array}{l}.110 \\
.157 \\
.259 \\
.259 \\
.315 \\
.315 \\
.047 \\
.102 \\
.102 \\
.205\end{array}$ & $\begin{array}{l}.0043 \\
.015 \\
.088 \\
.088 \\
.199 \\
.199 \\
.49 \\
.0015 \\
.199 \\
.199 \\
.199 \\
.199 \\
.199 \\
.199 \\
.199 \\
.199 \\
.199\end{array}$ & $\begin{array}{l}.0745 \\
.142 \\
.384 \\
.384 \\
.588 \\
.588 \\
.92 \\
.030 \\
.588 \\
.588 \\
.588 \\
.588 \\
.588 \\
.588 \\
.588 \\
.588 \\
.588\end{array}$ & $\begin{array}{l}.0085 \\
.028 \\
.144 \\
.136 \\
.337 \\
.336 \\
.879 \\
.033 \\
.485 \\
.566 \\
.572 \\
.638 \\
.626 \\
.372 \\
.422 \\
.427 \\
.537\end{array}$ & $\begin{array}{l}.058 \\
.106 \\
.229 \\
.229 \\
.338 \\
.338 \\
.533 \\
.050 \\
.338\end{array}$ \\
\hline
\end{tabular}

(A) See CN-3525, Fig. 18 .

(AA) Determined by Peter C. Mayer

(B) Calculated from the data of Stover and Crandall, UCRL-649. It was assumed that the nitric acid distrivutiun and not cnange with the addition of $\mathrm{NaNO}_{3} \cdot$

$866 \quad 16$ 
Table III

Distribution of Uranium (VI) in Pentaether-TTA-Nitric Acid Mixtures

\begin{tabular}{|c|c|c|c|c|c|c|}
\hline Ex.No. & $\begin{array}{l}\text { Initial } \\
\text { HNO, } \mathrm{M}\end{array}$ & $\begin{array}{l}\text { Equil. } \\
\mathrm{HNO}_{3} \mathrm{M}\end{array}$ & $\begin{array}{c}\text { TTA } \\
\underline{M}\end{array}$ & $\left(E_{M}-E_{1}\right)$ & $\left(E_{M}-E_{1}\right)$ calc. $\quad K_{2}$ & $\mathrm{~K}_{3}$ \\
\hline $\begin{array}{l}\mathrm{C} 24 \\
\mathrm{C} 25 \\
\mathrm{C} 26 \\
\mathrm{C} 27 \\
\mathrm{C} 28 \\
\mathrm{C} 29\end{array}$ & .0788 & .0745 & $\begin{array}{l}.0453 \\
.0755 \\
.151 \\
.227 \\
.302 \\
.378\end{array}$ & $\begin{array}{l}.411 \\
1.10 \\
5.00 \\
10.2 \\
20.6 \\
31.5\end{array}$ & $\begin{array}{c}\mathrm{K}_{2}=.15 \\
\mathrm{~K}_{3}=\frac{1}{.13} 5 \\
1.2 \mathrm{U} \\
4.75 \\
10.7 \\
18.9 \\
29.7\end{array}$ & $\begin{array}{l}1.11^{*} \\
1.07 \\
1.22 \\
1.11 \\
1.26 \\
1.22\end{array}$ \\
\hline
\end{tabular}

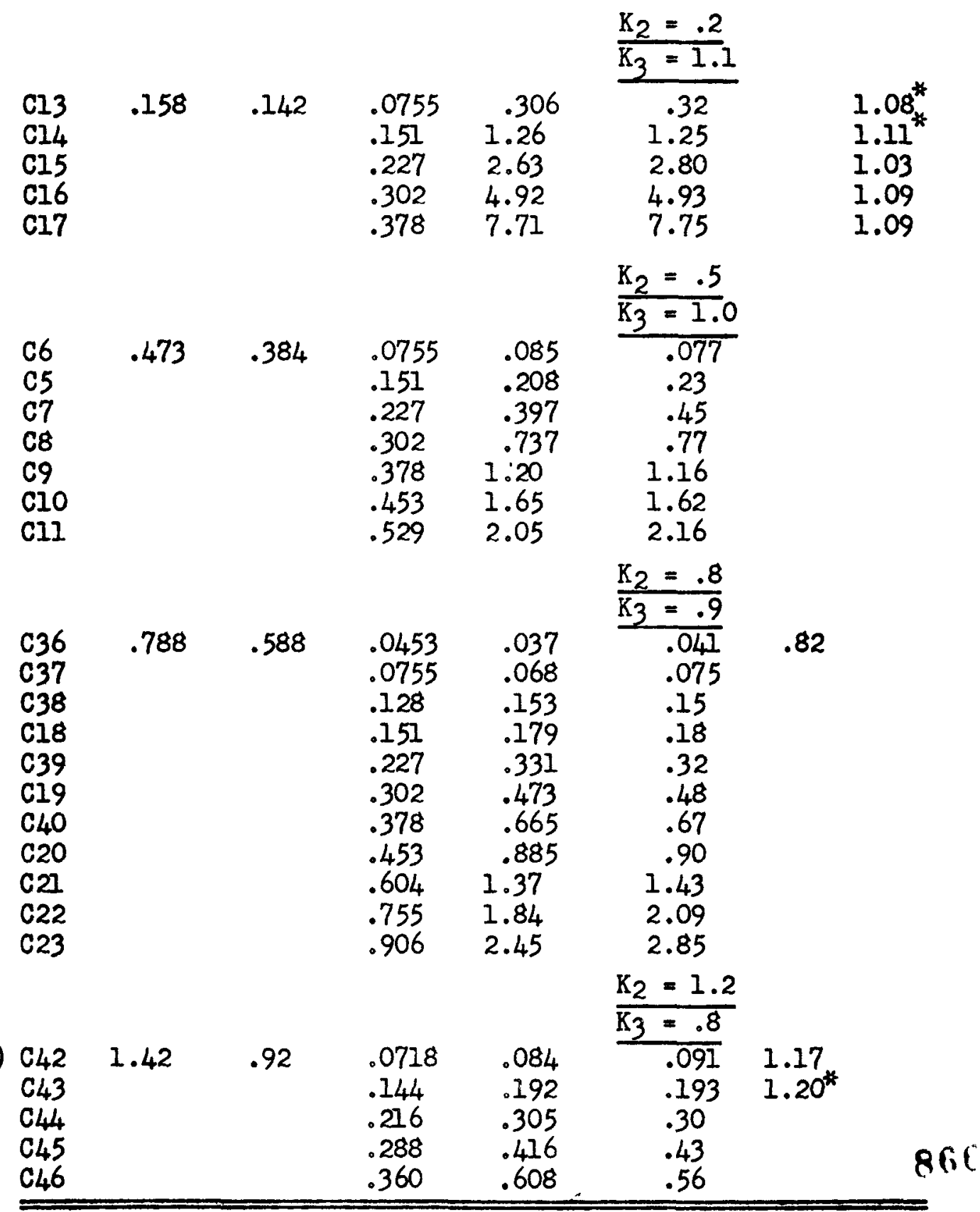


Table IV

Distribution of Uranium (VI) in Pentaether-TTA-Nitric Acid Mixtures Nitrate Ion Dependence

Ex.No. Initial Equil. $\mathrm{HNO}_{3} \mathrm{M} \quad \mathrm{HNO}_{3} \mathrm{M} \quad \mathrm{NaNO}_{3} \mathrm{M}$ TTAM Total

$$
\begin{array}{lllll}
E_{M} & E_{1} & \left(E_{M}-E_{1}\right) & \left(E_{M}-E_{1}\right) & K_{3}
\end{array}
$$
$\mathrm{NO}_{3}-\mathrm{M}$

\begin{tabular}{|c|c|c|c|c|c|c|c|c|}
\hline $\begin{array}{l}C 18 \\
C 47 \\
C 48 \\
C 64 \\
C 49 \\
C 50 \\
C 60 \\
C 66 \\
C 52 \\
C 61\end{array}$ & .788 & .588 & $\begin{array}{l}0 \\
.047 \\
.102 \\
.102 \\
.157 \\
.205 \\
.259 \\
.259 \\
.315 \\
.315\end{array}$ & .151 & $\begin{array}{l}.588 \\
.635 \\
.690 \\
.690 \\
.745 \\
.793 \\
.847 \\
.847 \\
.903 \\
.903\end{array}$ & $\begin{array}{l}.515 \\
.575 \\
.665 \\
.665 \\
.730 \\
.822 \\
.885 \\
.866 \\
.948 \\
.940\end{array}$ & $\begin{array}{l}.336 \\
.372 \\
.425 \\
.425 \\
.485 \\
.537 \\
.569 \\
.569 \\
.632 \\
.632\end{array}$ & $\begin{array}{l}.179 \\
.203 \\
.240 \\
.240 \\
.245 \\
.285 \\
.316 \\
.297 \\
.316 \\
.308\end{array}$ \\
\hline
\end{tabular}

Hydrogen Ion Dependence

\begin{tabular}{lllllllllll} 
C31 & .0315 & .030 & .110 & .0755 & .140 & 6.56 & .03 & 6.53 & 7.0 & $1.03^{*}$ \\
C32 & .0473 & .045 & .095 & & .140 & 2.95 & & 2.92 & 3.15 & $1.04^{*}$ \\
C33 & .0788 & .075 & .063 & & .138 & 1.10 & & 1.07 & 1.15 & $1.06^{*}$ \\
C34 & .110 & .103 & .039 & & .142 & .59 & & .56 & .61 & $1.04^{*}$ \\
C35 & .134 & .124 & .016 & & .140 & .37 & .34 & .43 & .92 \\
C13 & .158 & .142 & 0 & & .142 & .33 & & .30 & .33 & 1.06 \\
\hline
\end{tabular}

* Explained in Calculation of Constants, p. 13. 
Table V

Distribution of Uranium (VI) in Cyclohexanone-TTA-Nitric Acid Mixtures

\begin{tabular}{|c|c|c|c|c|c|c|c|}
\hline Ex. No. & $\begin{array}{l}\text { Initial } \\
\text { hivO }_{3} \underline{ }\end{array}$ & $\begin{array}{l}\text { Equil. } \\
\mathrm{HNO}_{3} \mathrm{M}\end{array}$ & $\stackrel{\mathrm{TTA}}{\underline{\mathrm{M}}}$ & $\left(E_{M}-E_{1}\right)$ & $\begin{array}{c}\left(\mathrm{E}_{\mathbf{M}^{-}} \mathrm{E}_{\mathbf{I}}\right) \\
\text { calc. }\end{array}$ & $\mathrm{K}_{2}$ & $\mathrm{~K}_{3}$ \\
\hline & & & & & $\begin{array}{l}\mathrm{K}_{2}=1.5 \\
\mathrm{~K}_{3}=1.09\end{array}$ & & \\
\hline \multirow[t]{2}{*}{$\begin{array}{l}\text { B55 } \\
\text { B56 } \\
\text { B57 } \\
\text { B58 } \\
\text { B59 } \\
\text { B } 60\end{array}$} & .0504 & .0479 & $\begin{array}{l}.0383 \\
.0765 \\
.115 \\
.153 \\
.191 \\
.230\end{array}$ & $\begin{array}{l}.709 \\
2.79 \\
6.19 \\
12.2 \\
16.5 \\
23.8\end{array}$ & $\begin{array}{c}.76 \\
2.9 \\
6.4 \\
11.4 \\
16.3 \\
23.4\end{array}$ & & $\begin{array}{l}1.11^{*} \\
1.09^{*} \\
1.08 \\
1.19 \\
1.04 \\
1.03\end{array}$ \\
\hline & & & & & $\begin{array}{l}K_{2}=2.0 \\
K_{3}=1.1\end{array}$ & & \\
\hline \multirow[t]{2}{*}{$\begin{array}{l}\text { B49 } \\
\text { B50 } \\
\text { B51 } \\
\text { B52 } \\
\text { B53 } \\
\text { B } 54\end{array}$} & .1008 & .0935 & $\begin{array}{l}.0383 \\
.0765 \\
.115 \\
.153 \\
.191 \\
.230\end{array}$ & $\begin{array}{l}.247 \\
.898 \\
1.96 \\
3.39 \\
4.36 \\
7.09\end{array}$ & $\begin{array}{r}.26 \\
.89 \\
1.89 \\
3.18 \\
4.98 \\
7.04\end{array}$ & & \\
\hline & & & & & $\frac{K_{2}=3.2}{K_{3}=.7}$ & & \\
\hline \multirow[t]{2}{*}{$\begin{array}{l}\text { B28 } \\
\text { B6 } \\
\text { B5 } \\
\text { B4 } \\
\text { B3 } \\
\text { B2 } \\
\text { B18 } \\
\text { B7 } \\
\text { B19 }\end{array}$} & .234 & .203 & $\begin{array}{l}.0383 \\
.0765 \\
.115 \\
.153 \\
.191 \\
.230 \\
.268 \\
.268 \\
.306\end{array}$ & $\begin{array}{l}.157 \\
.420 \\
.624 \\
.945 \\
1.24 \\
1.45 \\
1.99 \\
2.12 \\
2.75\end{array}$ & $\begin{array}{l}.15 \\
.34 \\
.60 \\
.89 \\
1.23 \\
1.64 \\
2.08 \\
2.08 \\
2.58\end{array}$ & & \\
\hline & & & & & $\begin{array}{l}K_{2}=5.0 \\
K_{3}=.10\end{array}$ & & \\
\hline $\begin{array}{l}\text { B14 } \\
\text { B13 } \\
\text { B12 } \\
\text { B8 } \\
\text { B9 } \\
\text { B10 } \\
\text { B11 } \\
\text { B15 }\end{array}$ & .479 & .385 & $\begin{array}{l}.0382 \\
.0765 \\
.153 \\
.230 \\
.306 \\
.383 \\
.459 \\
.536\end{array}$ & $\begin{array}{c}.184 \\
.395 \\
.792 \\
1.18 \\
1.51 \\
1.92 \\
2.21 \\
2.81\end{array}$ & $\begin{array}{l}.19 \\
.39 \\
.78 \\
1.19 \\
1.59 \\
2.02 \\
2.44 \\
2.87\end{array}$ & $\begin{array}{l}4.82 \\
5.16 \\
5.18^{*} \\
5.14^{*} \\
4.93^{*} \\
5.02^{*} \\
4.81^{*} \\
5.24^{*}\end{array}$ & \\
\hline
\end{tabular}

*Explained in Calculation of Constants, p. 13. 
Table VI

Distribution of Uranium (VI) in Cyclohexanone-TTA-Nitric Acid Mixtures Hydrogen Ion Dependence

\begin{tabular}{|c|c|c|c|c|c|c|c|c|c|c|}
\hline c. No. & $\begin{array}{l}\text { Initial } \\
\text { hwOH }_{3} \mathrm{M}\end{array}$ & $\begin{array}{l}\text { Equil. } \\
\mathrm{HNO}_{3} \mathrm{M}\end{array}$ & $\underset{\mathrm{M}}{\mathrm{NaNO}_{3}}$ & $\begin{array}{c}\mathrm{TTA} \\
\underline{M}\end{array}$ & $\begin{array}{l}\text { Equil. } \\
\mathrm{NO}_{3}-\mathrm{M}\end{array}$ & $E_{M}$ & $E_{1}$ & $\left(E_{M}-E_{\eta}\right)$ & $\begin{array}{c}\left(E_{M} E_{1}\right) \\
\text { calc. }\end{array}$ & $\mathrm{K}_{2}$ \\
\hline & & & & & & & & & $\mathrm{K}_{2}=5.2$ & \\
\hline $\begin{array}{l}+3 \\
+2 \\
41 \\
25\end{array}$ & $\begin{array}{l}.473 \\
.630 \\
.788 \\
.985 \\
.985\end{array}$ & $\begin{array}{l}.380 \\
.491 \\
.602 \\
.739 \\
.739\end{array}$ & $\begin{array}{l}.362 \\
.248 \\
.142 \\
0 \\
0\end{array}$ & $\begin{array}{l}.153 \\
.153 \\
.153 \\
.153 \\
.153\end{array}$ & $\begin{array}{l}.742 \\
.739 \\
.744 \\
.739 \\
.739\end{array}$ & $\begin{array}{l}2.13 \\
1.74 \\
1.49 \\
1.27 \\
1.42\end{array}$ & $\begin{array}{l}.54 \\
.54 \\
.54 \\
.54 \\
.54\end{array}$ & $\begin{array}{r}1.59 \\
1.20 \\
.95 \\
.73 \\
.88\end{array}$ & $\begin{array}{r}1.55 \\
1.20 \\
.98 \\
.80 \\
.80\end{array}$ & $\begin{array}{l}5.14 \\
5.04 \\
4.78 \\
5.74\end{array}$ \\
\hline
\end{tabular}

Nitrate Ion Dependence

$\begin{array}{llllllllll}\text { B43 } & .473 & .380 & .362 & .153 & .742 & 2.13 & .54 & 1.59 & 5.32^{*} \\ \text { B45 } & .473 & .380 & .263 & .153 & .616 & 1.65 & .41 & 1.24 & 4.98^{*} \\ \text { B12 } & .473 & .380 & .0 & .153 & .380 & .97 & .18 & .79 & 5.16^{*} \\ \text { B41 } & .788 & .602 & .142 & .153 & .744 & 1.49 & .54 & .95 & 5.04 \\ \text { B33 } & .788 & .602 & .291 & .153 & .893 & 2.13 & .64 & 1.49 & 6.56 \\ \text { B24 } & .788 & .602 & .197 & .153 & .799 & 1.62 & .57 & 1.05 & 5.19 \\ \text { B40 } & .788 & .602 & 00 & .153 & .602 & 1.17 & .41 & .76 & 4.97\end{array}$

*Explained in Calculation of Cunstants, P. 13.

Table VII

Distribution of Uranium (VI) in Hexone-TTA-Nitric Acid Mixtures

\begin{tabular}{|c|c|c|c|c|}
\hline Ex.No. & $\begin{array}{l}\text { Initial } \\
\mathrm{HNO}_{3} \mathrm{M}\end{array}$ & $\begin{array}{l}\text { Equil. } \\
\mathrm{HNO}_{3} \mathrm{M}\end{array}$ & $\begin{array}{c}\text { TTA } \\
\underline{M}\end{array}$ & $E_{M}$ \\
\hline A19 & .479 & .454 & .563 & 1.08 \\
\hline $\begin{array}{l}\text { A5 } \\
\text { A10 } \\
\text { A9 } \\
\text { A8 }\end{array}$ & $\begin{array}{l}.444 \\
.444 \\
.444 \\
.444\end{array}$ & $\begin{array}{l}.423 \\
.423 \\
.423 \\
.423\end{array}$ & $\begin{array}{l}.375 \\
.375 \\
.563 \\
.751\end{array}$ & $\begin{array}{r}.554 \\
.604 \\
1.100 \\
1.790\end{array}$ \\
\hline $\begin{array}{l}\text { A12 } \\
\text { A17 } \\
\text { A18 } \\
\text { A20 }\end{array}$ & $\begin{array}{l}.350 \\
.350 \\
.350 \\
.350\end{array}$ & $\begin{array}{l}.339 \\
.339 \\
.339 \\
.339\end{array}$ & $\begin{array}{l}.375 \\
.563 \\
.563 \\
.563\end{array}$ & $\begin{array}{l}.834 \\
1.46 \\
1.52 \\
1.86\end{array}$ \\
\hline $\begin{array}{l}\text { A16 } \\
\text { A15 } \\
\text { A11 } \\
\text { A13 } \\
\text { Al4 }\end{array}$ & $\begin{array}{l}.234 \\
.234 \\
.234 \\
.234 \\
.234\end{array}$ & $\begin{array}{l}.229 \\
.229 \\
.229 \\
.229 \\
.229\end{array}$ & $\begin{array}{l}.150 \\
.225 \\
.375 \\
.563 \\
.563\end{array}$ & $\begin{array}{l}.336 \\
.756 \\
1.71 \\
3.83 \\
3.74\end{array}$ \\
\hline
\end{tabular}


Table VIII

Comparison of the Contributions of the Terms

$$
\mathrm{K}_{3}\left(\frac{\mathrm{HK}}{\mathrm{H}^{+}}\right)^{2} \text { and } \frac{(\mathrm{HK})\left(\mathrm{NO}_{3}^{-}\right)}{\left(\mathrm{H}^{+}\right)} \mathrm{K}_{2} \text { to }\left(\mathrm{E}_{\mathrm{M}^{-}} \mathrm{E}_{1}\right)
$$

Measured in Pentaether

\begin{tabular}{|c|c|c|c|c|c|c|}
\hline Ex. No. & $\begin{array}{l}\text { Equil. } \\
\mathrm{HNO}_{3} \mathrm{M}\end{array}$ & $\stackrel{\text { TTA }}{\underline{M}}$ & $\frac{(\mathrm{HK})\left(\mathrm{NO}_{3}{ }^{-}\right)}{\left(\mathrm{H}^{+}\right)} \mathrm{K}_{2}$ & $\left(\frac{\mathrm{HK}}{\mathrm{H}^{+}}\right)^{2} \mathrm{~K}_{3}$ & $\begin{array}{l}\left(E_{M}-E_{7}\right) \\
\text { Measured }\end{array}$ & $\begin{array}{l}\text { Max. Contri- } \\
\text { bution of } \\
\left(\frac{\mathrm{HK}}{\mathrm{H}^{+}}\right)\left(\mathrm{NO}_{3}-\right)^{\mathrm{K}_{2}} \\
\text { to }\left(\mathrm{E}_{\mathrm{M}}-\mathrm{E}_{1}\right) \text { mes } \\
\quad \not 6\end{array}$ \\
\hline $\begin{array}{l}C 24 \\
C 25 \\
C 26 \\
C 27 \\
C 28 \\
C 20\end{array}$ & .0745 & $\begin{array}{l}.0453 \\
.0755 \\
.151 \\
.227 \\
.302 \\
.379\end{array}$ & $\begin{array}{l}.054 \\
.091 \\
.181 \\
.272 \\
.362 \\
.454\end{array}$ & $\begin{array}{l}.426 \\
1.18 \\
4.71 \\
10.7 \\
18.9 \\
29.7\end{array}$ & $\begin{array}{l}.411 \\
1.10 \\
5.00 \\
10.2 \\
20.6 \\
31.5\end{array}$ & $\begin{array}{c}13 \\
8 \\
4 \\
3 \\
2 \\
1.5\end{array}$ \\
\hline
\end{tabular}

$$
\begin{aligned}
& \left(\mathrm{E}_{\mathrm{M}}-\mathrm{E}_{1}\right)=\left(\frac{\mathrm{HK}}{\mathrm{H}^{+}}\right)^{2} \mathrm{~K}_{3}+\frac{(\mathrm{HK})\left(\mathrm{NO}_{3}^{-}\right)}{\left(\mathrm{H}^{+}\right)} \mathrm{K}_{2} \quad \mathrm{~K}_{3} \mathrm{Max} .=1.15 \\
& \mathrm{~K}_{2} \text { Max. }=1.2
\end{aligned}
$$

Max. Contribution of $\left(\frac{\mathrm{HK}}{\mathrm{H}^{+}}\right)^{2} \mathrm{~K}_{3}$ to $\left(\mathrm{E}_{\mathrm{M}}-\mathrm{E}_{1}\right)$ measured $\%$

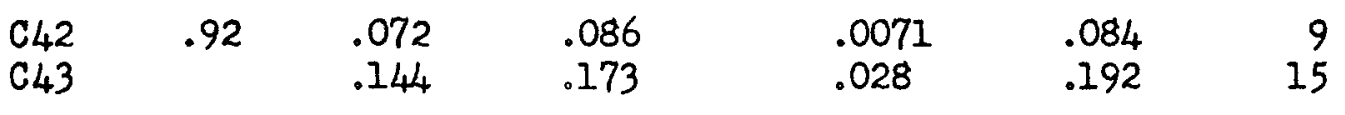




\section{REFERENCES}

1. TTA is thenoyltrifluoroacetone,<smiles>CC(C)(C)CC(=O)c1cccs1</smiles>

The symbol HK represents the TTA molecule while $\mathrm{K}^{-}$represents that part of the molecule which remains after the removal of a proton.

2. E. L. King, Manhattan Project Metallurgical Laboratory Report CC-3618 (Aug., 1946).

3. W. C. Orr, UCRL-196.

4. E. K. Hyde and J. Tolmach, ANL-4248.

5. E. I. King and W. H. Reas, AECD-2573.

6. H. W. Crandall and D. L. Heisig, UCRL-778.

7. KAPL-94, p. 22 .

8. R. H. Betts and Rita K. Michels, JCS, Supplementary Issue No. 2 (1949), p. 286.

9. Manhattan Project Metallurgical Laboratory Report CN-3525, Figure 18.

10. C. N. Stover, Jr. and H. W. Crandall, UCRL -649.

11. E. Abel, 0. Redlick, B. Lengyel, Z. Phys. Chem. 132, 189

12. R. A. Robinson, J. M. Wilson, and H. S. Ayling, J. Am. Chem. Soc. 64, 1469 (1942). 
UCRL 764

Page 24

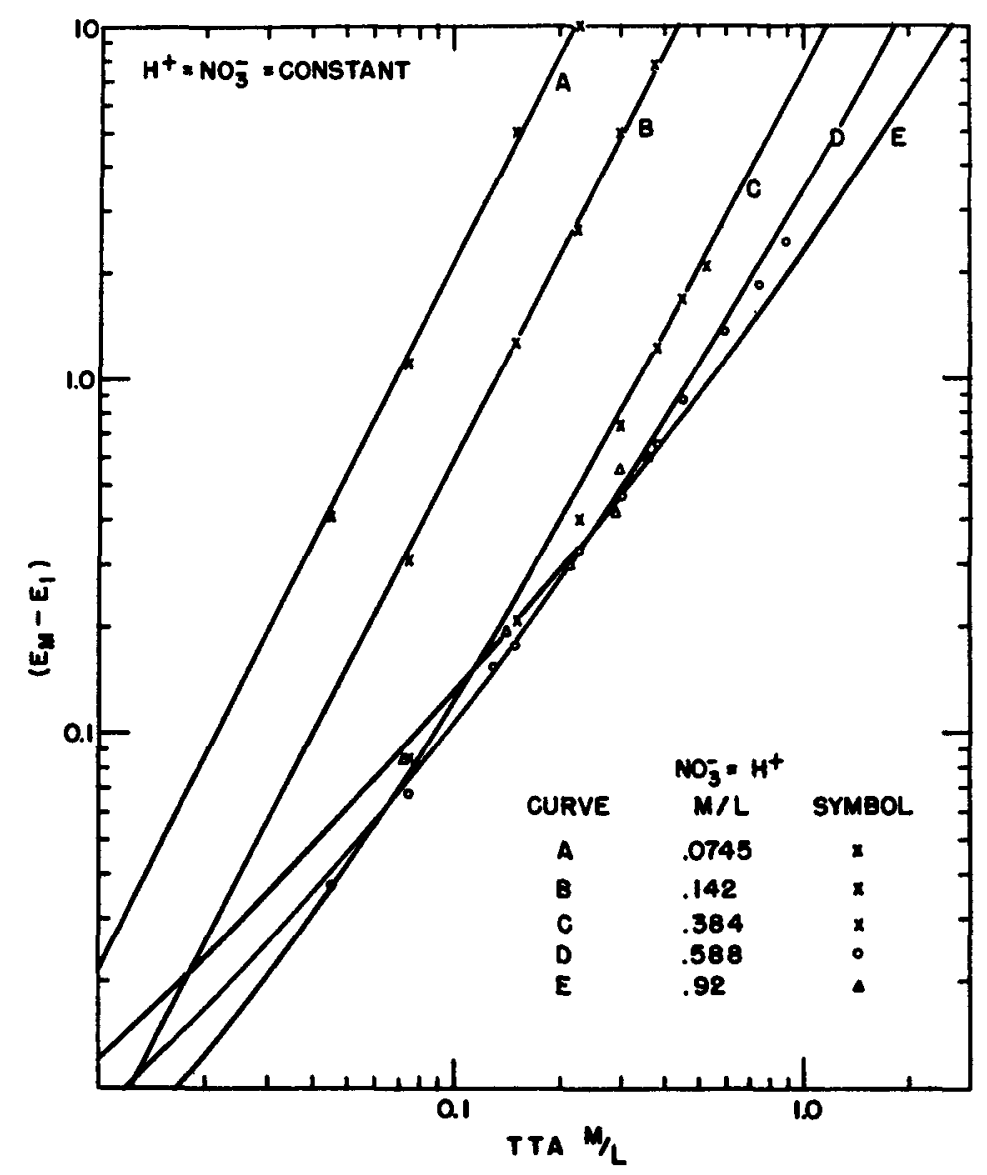

(FROM THE DATA IN TABLE III)

VARIATION OF THE URANIUM (III) DISTRIBUTION COEFFICIENT IN PENTAETHER WITH THE TTA CONCENTRATION.

Fi6. 1 MU 462

Ition 


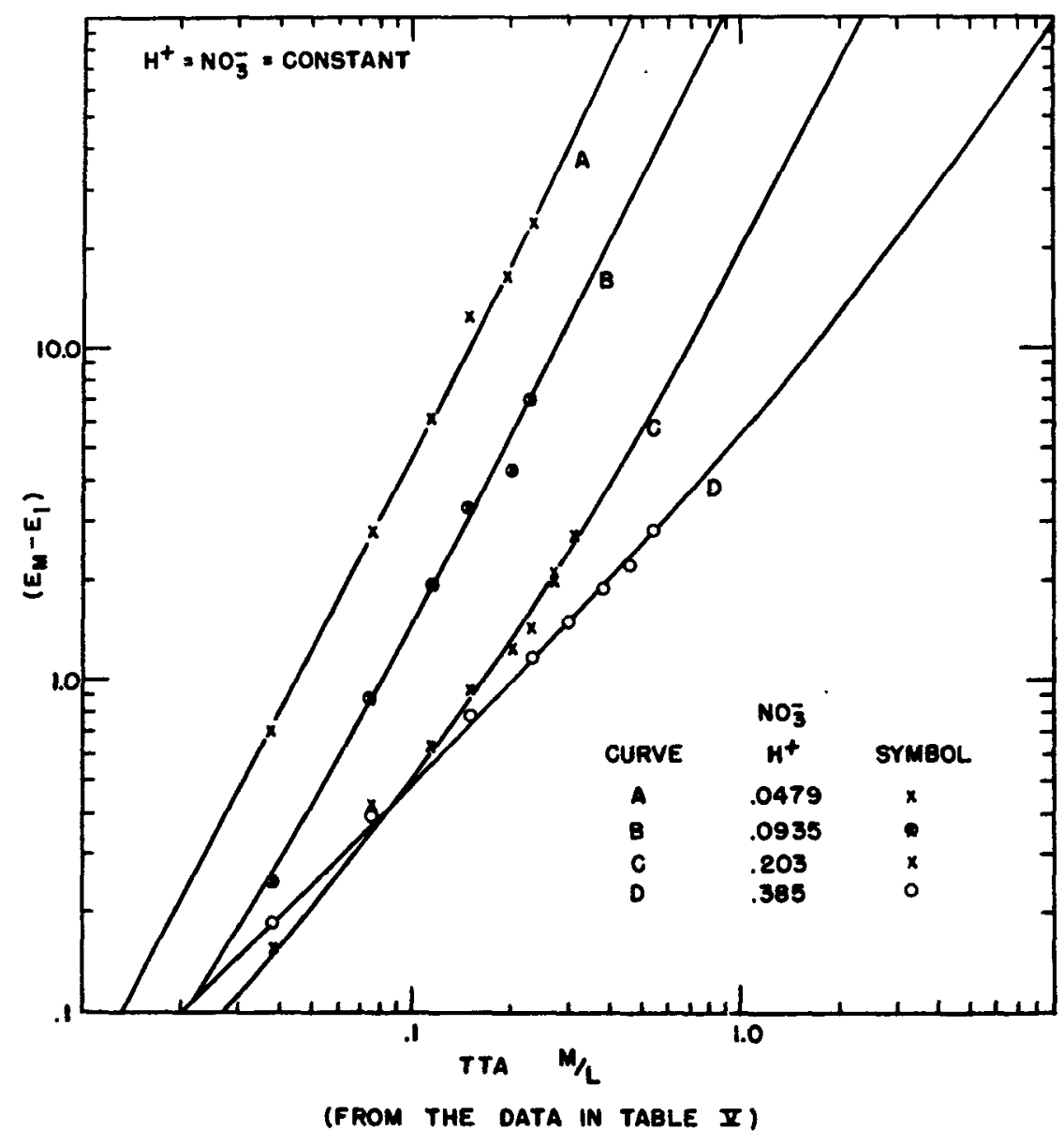

VARIATION OF THE URANIUM (WI) DISTRIBUTION COEFFICIENT IN CYCLOHEXANONE WITH THE TTA GONCENTRATION.

FIG. 2 MU 463 


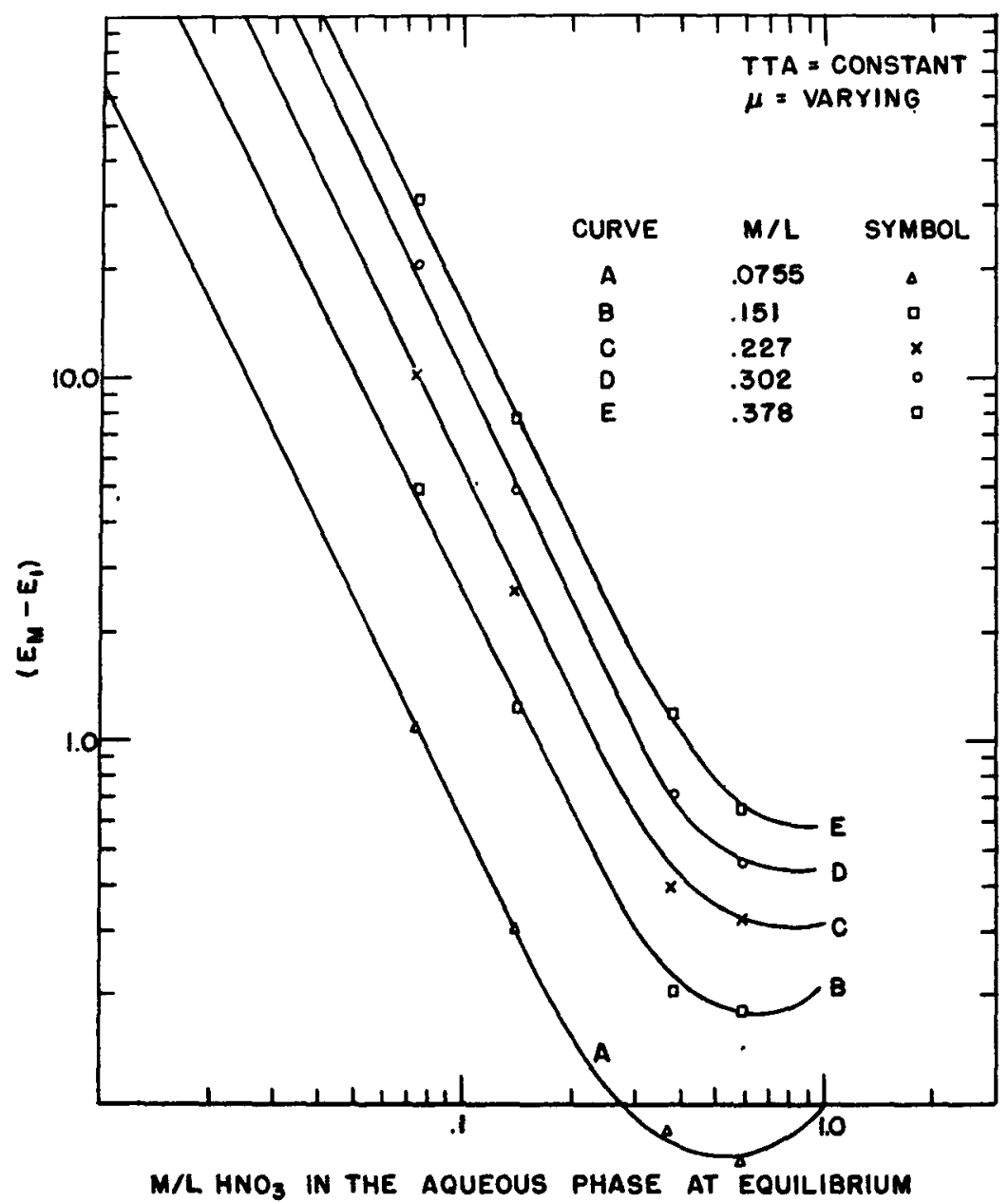

VARIATION OF THE URANIUM(II) DISTRIBUTION COEFFICIENT IN PENTAETHER WITH THE NITRIC ACID CONCENTRATION.

(FROM THE DATA IN TABLE III)

FIG. 3

MU 464.

19110 


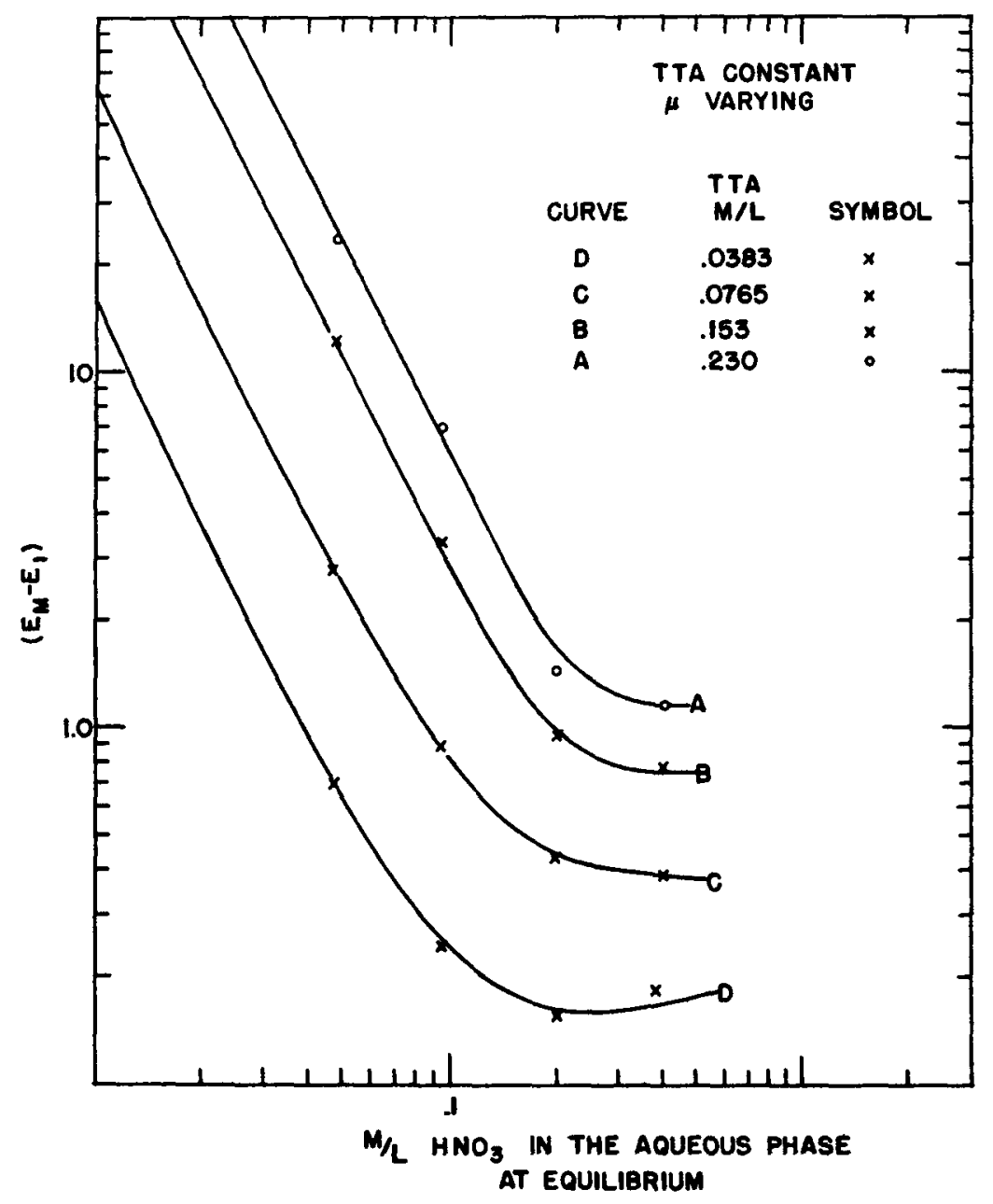

(FROM THE DATA IN TABLE $\mathbf{Z}$ )

VARIATION OF THE URANIUM (III) DISTRIBUTION COEFFICIENT IN CYCLOHEXANONE WITH THE NITRIC ACID CONCENTRATION

FIG. 4

MU 465 


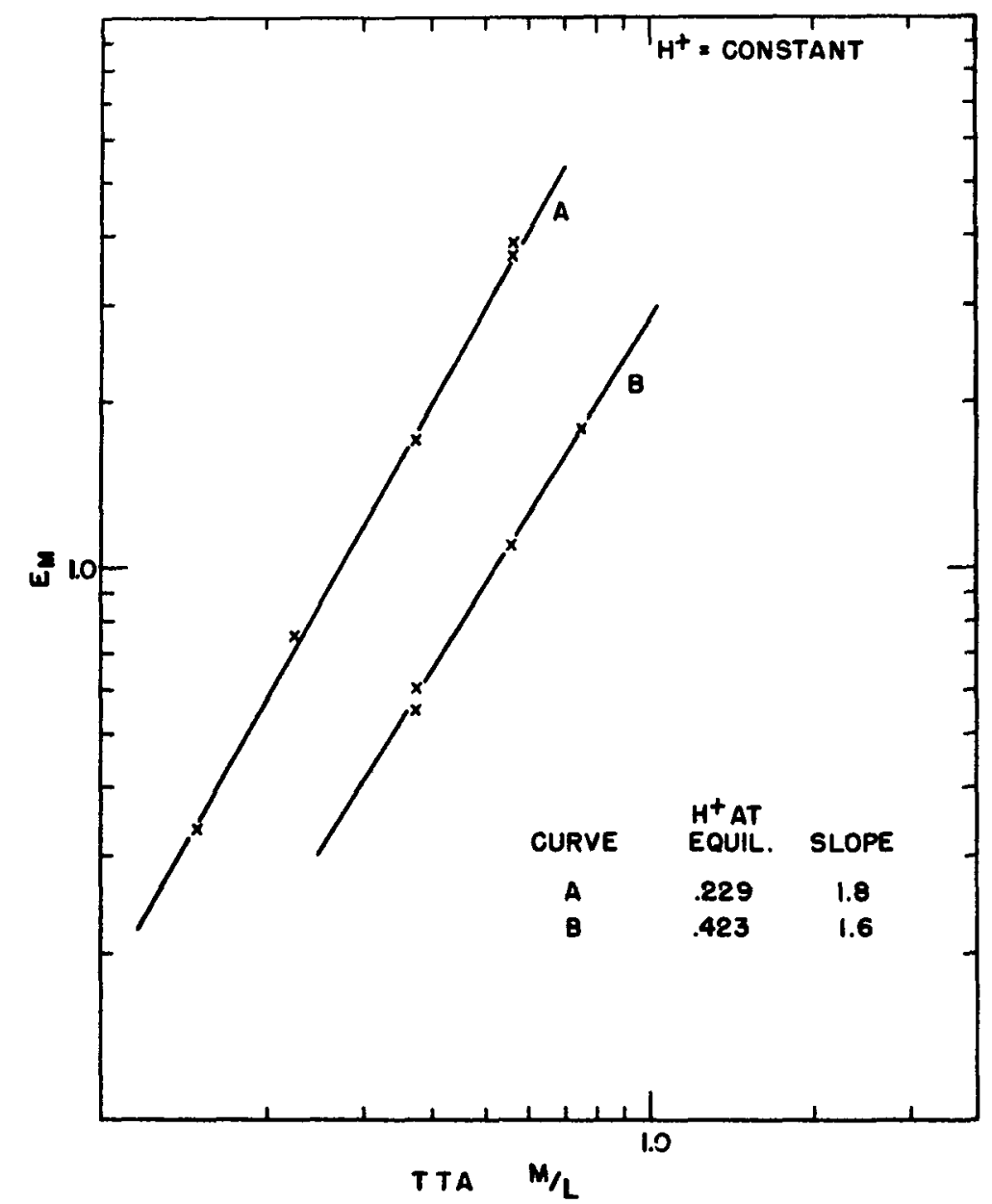

(FROM THE DATA IN TABLE III)

VARIATION OF THE URANIUM (ZI) DISTRIBUTION COEFFICIENT IN HEXONE WITH THE TTA CONCENTRATION.

FIG. 5 


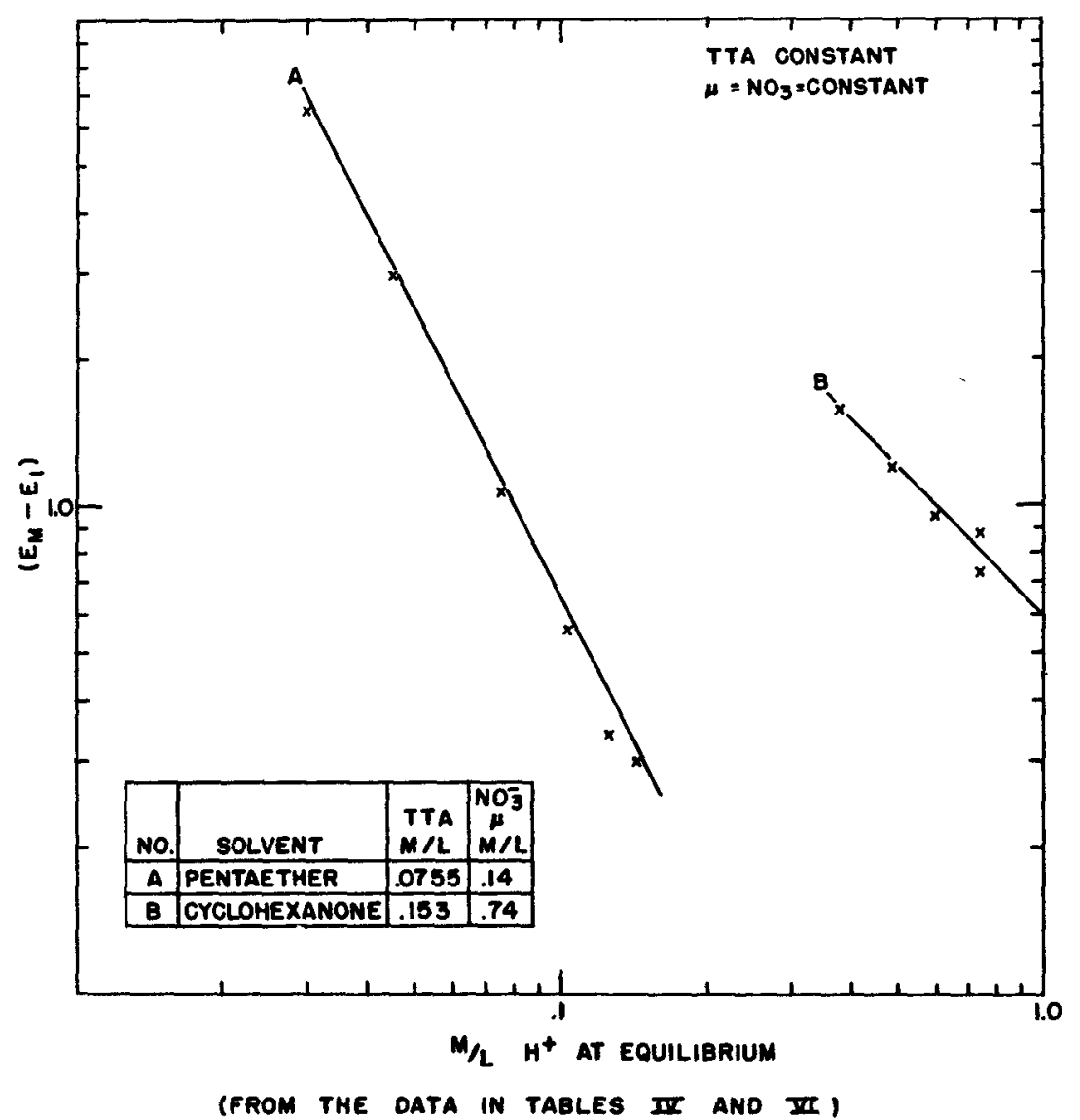

VARIATION OF THE URANIUM (ZII) DISTRIBUTION COEFFICIENT

WITH THE HYDROGEN ION CONCENTRATION.

FIG. 6

MU 467 -

161131 


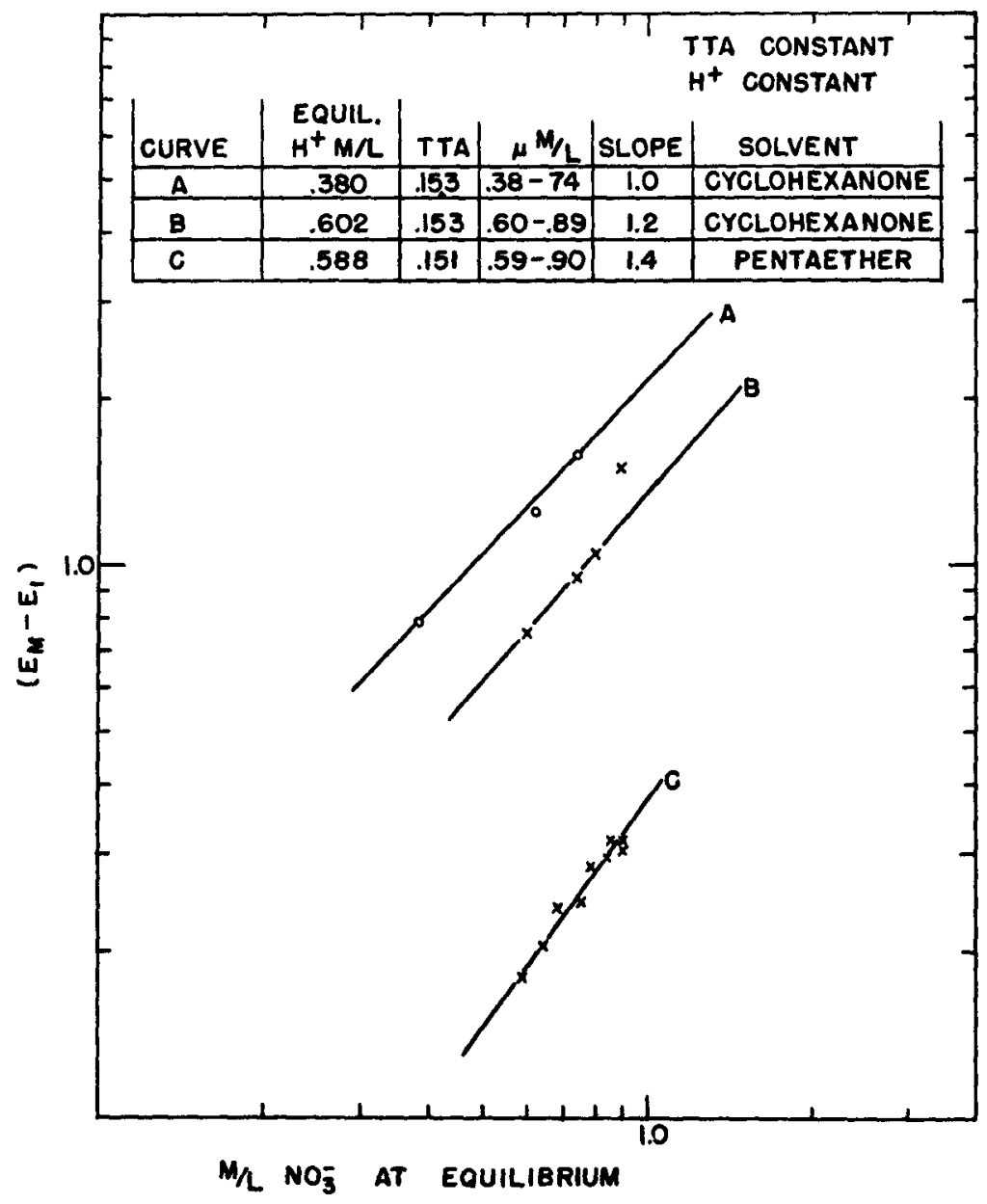

(FROM THE DATA IN TABLES I AND III)

VARIATION OF THE URANIUM (ZI) DISTRIBUTION COEFFICIENT WITH NITRATE . ION CONCENTRATION.

FIG. 7

MU 468

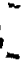

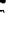

$-$

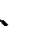

.

86 


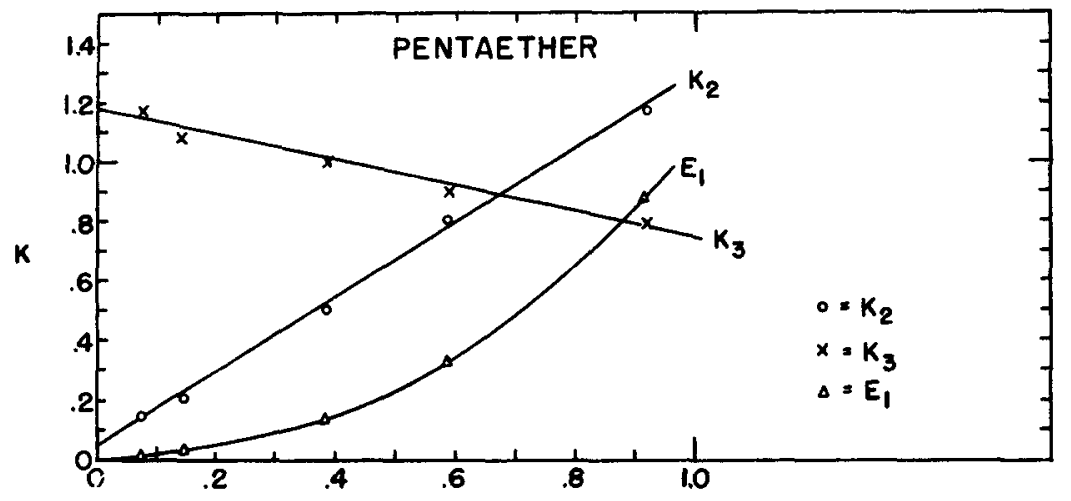

$\mathrm{M} / \mathrm{L} \mathrm{HNO}_{3}$ IN THE AQUEOUS PHASE AT EQUILIBRIUM

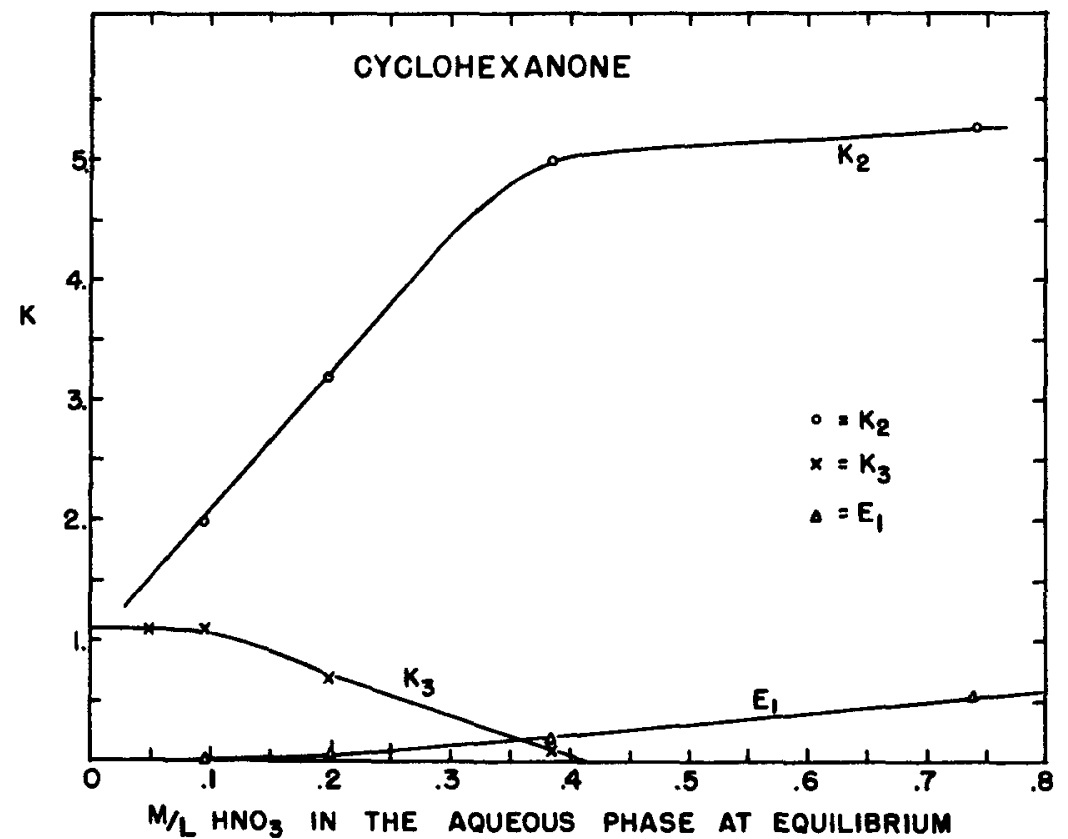

SUMMARY OF CONSTANTS AT VARIOUS NITRIC ACIO CONCENTRATIONS

FIG. 8 MU 469 